University of Louisville

ThinkIR: The University of Louisville's Institutional Repository

Electronic Theses and Dissertations

$5-2007$

\title{
Ambiguity and triangles : United States policy and action during the referendum crisis of 2003-4.
}

William David Frost 1982-

University of Louisville

Follow this and additional works at: https://ir.library.louisville.edu/etd

\section{Recommended Citation}

Frost, William David 1982-, "Ambiguity and triangles : United States policy and action during the referendum crisis of 2003-4." (2007). Electronic Theses and Dissertations. Paper 465.

https://doi.org/10.18297/etd/465

This Master's Thesis is brought to you for free and open access by ThinkIR: The University of Louisville's Institutional Repository. It has been accepted for inclusion in Electronic Theses and Dissertations by an authorized administrator of ThinkIR: The University of Louisville's Institutional Repository. This title appears here courtesy of the author, who has retained all other copyrights. For more information, please contact thinkir@louisville.edu. 


\title{
AMBIGUITY AND TRIANGLES: US POLICY AND ACTION DURING THE REFERENDUM CRISIS OF 2003-4
}

\author{
By \\ Wm. David Frost \\ B.A., Oberlin College, 2004
}

A Thesis Submitted to the Faculty of the Graduate School of the University of Louisville in Partial Fulfillment of the Requirements for the Degree of

Master of Arts

Department of Political Science

University of Louisville

Louisville, KY

May 2007 


\title{
AMBIGUITY AND TRIANGLES: US POLICY AND ACTION DURING THE REFERENDUM CRISIS OF 2003-4
}

\author{
By \\ Wm. David Frost \\ B.A., Oberlin College, 2004
}

A Thesis Approved on

March 30, 2007

By the following Thesis Committee:

Thesis Director, Shiping Hua

Robert St. Clair

Rodger Payne 


\section{ACKNOWLEDGEMENTS}

I would like to thank all of the people who gave me the encouragement and support necessary to write and finish this work. In particular, I would like to thank Dr. Shiping Hua. His wisdom helped to inform a great deal of my thinking on the issue, even on areas where we disagreed, and his support has been unflagging. I would also like to thanks Dr. Rodger Payne and Dr. Robert St. Clair for their assistance with this project. Lastly, I would like thank Dr. Laurie Rhodebeck for all of her assistance and advice. 


\section{ABSTRACT \\ AMBIGUITY AND TRIANGLES: US POLICY AND ACTION DURING THE REFERENDUM CRISIS OF 2003-4}

Wm. David Frost

March 30, 2007

During the 2004 Presidential Election in the Republic of China, President Chen Shui-bian proposed two referenda. These referenda dealt with relations with the People's Republic of China. The People's Republic of China reacted very strongly against the referenda, even before the full nature of the referenda was known, and tensions ran high between the two states through the run-up to the election.

United States President George W. Bush also made statements against the refcrenda, but did not take much action to exert pressure on the ROC. Instead the US worked instead to maintain strong relations with both while maintaining the rhetoric of working to relieve tension. In effect, the US talked deterrence while instead maintaining the strategic triangle at work.

This work breaks down US reaction to the crisis through the two systems of deterrence and strategic triangle theory, in order to better understand the priorities and actions of the Bush administration. In doing so, it becomes evident that the ROC, while not achieving everything its leadership hoped, came out best from the crisis, while the PRC lost credibility. Moreover, while the credibility of the US commitment to peace might have been strained, the US did not benefit or lose too much from the crisis. While it may still be too early to be certain, it seems that the Bush administration's decision to protect American relationships with both the PRC and ROC was the best approach open. 
TABLE OF CONTENTS

PAGE

ACKNOWLEDGEMENTS .............................................

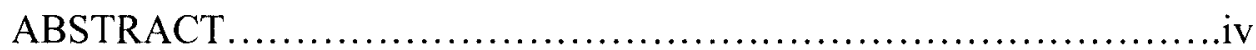

CHAPTER

I. INTRODUCTION ......................................

II. THEORY AND LITERATURE REVIEW .................4

III. HISTORY OF THE TAIWAN STRAIT ISSUE............14

IV. POLICY AND ACTION..................................21

V. CONCLUSIONS.......................................45

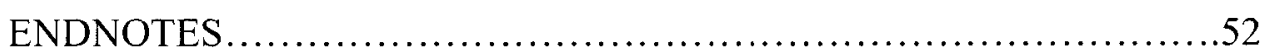

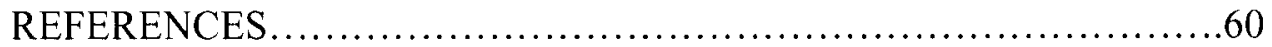

CURRICULUM VITAE ............................................... 62 


\section{CHAPTER I \\ INTRODUCTION}

Relations between the People's Republic of China (PRC) and the Republic of China (ROC) have been tense ever since the end of the Chinese Civil War in 1949. Since the end of the Cold War, the United States (US) has tried to maintain good relations with both the PRC and the ROC despite the antagonism between them, and has often tried to act to keep tensions between the two from turning into war. However, in recent years, with its attention drawn largely away from East Asia to the Middle East, the ability of the United States to affect outcomes in the region has eroded considerably.

On December 6, 2003, during the run-up to an election in the Republic of China (or, more commonly, Taiwan), President Chen Shui-bian declared his wish to hold a referendum that, if passed, would demand the People's Republic of China to point its missiles in a different direction. He also wished to introduce a second referendum to demand that China renounce the use of force in order to reunite the country. ${ }^{1}$ The Chinese Premier, Wen Jiabao, after meeting with US President George W. Bush, said that he felt that the referendum was an attempt to split Taiwan from China, and would not be tolerated. President Bush backed up Wen, claiming that President Chen should not do anything that unilaterally changed the status quo. ${ }^{2}$

Thus began the worst crisis in the Taiwan Strait since 1996, when President Clinton sent two carrier groups into the Strait. The Chinese rhetoric increased quite 
significantly while Chen alternated between claiming the referendum as the ROC's right and claiming that it was not as bad as the PRC made it out to be. The United States, on the other hand, felt locked into a position that amounted to no position; it consistently stated merely that it was opposed to any "unilateral change in the status quo." As the situation progressed, small changes were made in rhetoric, but no conclusion was reached and the ROC went through with the referenda. Through the whole crisis, the US, while talking often, made few demands and committed few actions.

This was due to a decision in Washington that prioritized the relationships with the PRC and the ROC, rather than reducing tensions. Rather than supporting the PRC, as some suggested it did, the US was instead issuing the right words to avoid offending either side, while simultaneously asking for calm. Due to the importance of both the PRC and the ROC to US Asian policy and the irreconcilable conflict between the two, Washington is stuck trying to preserve its version of the status quo despite efforts by either Taiwan or China to change it. Moreover, while most previous administrations were able to tack back and forth between the two, shifting support from one side to the other to keep both sides happy and docile, this administration completely lacked either the attention or the means to do so. The US instead tried, in the 2004 crisis, for "cheap ambiguity." The US maintained ambiguous talk, but this was merely "cheap talk." The US imposed no penalties and offered no inducements to either side.

Its actions thus comport more closely to what is expected from strategic triangles theory than to deterrence theory. This is important for understanding how future crises might play out during this same administration. This can be seen more clearly by examining the actions taken by the US, the PRC, and the ROC, and the interplay of those actions, during the "referendum crisis" of 2004. This examination of the different moves 
and strategies undertaken by the three players will show that, at the time of the crisis, the United States was much more interested in preserving its relationships then in resolving the crisis.

This thesis has been broken down into three chapters. The first chapter examines the theories that are most often used to examine the Taiwan Strait crisis, deterrence and strategic triangle theory, and the relative strengths and weaknesses of each, and explain why both theories are needed together to study the crisis. The second chapter will examine the historical background of Taiwan and its unique status. The third chapter is the analysis of the referendum and US policy, and how US policy followed the logic of strategic triangles, rather than deterrence. This includes an overview of US policy, focusing on the communiqués and the Taiwan Relations Act, as well as general interpretations of the policies and interests of the PRC and ROC. All this is followed by a swift conclusion and overview of the arguments involved. 


\section{CHAPTER II \\ THEORY AND LITERATURE REVIEW}

The Taiwan Straits problem is one of the most salient flash points in the world today. Any discussion of the literature of the problem will be, by necessity, abbreviated. However, an attempt to discuss the relevant theories and concepts is essential.

It must be understood that this analysis is, in a sense, exploratory. The referendum crisis, while occasionally mentioned in other analyses, ${ }^{3}$ has not been studied in the depth it deserves. It is amazing that, three years later, there have been no scholarly works focusing exclusively on the referendum crisis.

The two most employed theoretical models for examining the Taiwan Strait crisis are deterrence theory and strategic triangle theory. Both, for the purposes of this analysis, have their strengths and weaknesses. Deterrence theory is strong in that it can give insights into both how policy is formed and what policy should be, but it has several difficulties in handling games with three autonomous actors. Strategic triangle theory, on the other hand, is made for three-party games and helps to explain relationships among them, but is not as useful for examining what policy should be. Therefore, both theories must be used in conjunction to examine and analyze the referendum fully.

US policy towards the Taiwan Strait is most often viewed through the lens of deterrence theory. Since American policy in the Taiwan Straits is to prevent either China or Taiwan from doing anything that would lead to war, it would seem to follow naturally 
that deterrence theory would be able to give clear insights into how the US should behave in order to get its maximal outcome. However, deterrence theory has so far not been able to formulate a good response for the United States due to the complex nature of this three-party game. To understand this, it is first necessary to understand what deterrence is, and what it says about conflict, ambiguity, and three-party systems.

Deterrence theory came out of the great power conflicts of Europe, and was developed further during the Cold War. In classical deterrence theory, most forms of ambiguity weaken the deterrent. Thomas Schelling's work, The Strategy of Conflict, ${ }^{4}$ lays out what is necessary in a deterrent. A deterrent must be believable and going through with it must put the original aggressor in a worse position than the status quo. He customarily used the word "threat" for any deterrent that caused both sides in the deterrence a worse position (after the original aggression), in the hope that it would convince the potential aggressor to stand down. This threat can be anything, and can take almost any form, as long as both are worse off for going through with the threat. ${ }^{5}$ In this example, if the US threatens war with the PRC for attacking Taiwan, both the US and the PRC will be worse off.

However, there is no reason for the PRC to believe that the US will act on such a threat, if it will make the US worse off as well. For a deterrent to work, the deterring party (in this case, the United States) needs to be in the position of being better off by following through than by not following through. In the case of threatening military attack or support, this is difficult to achieve. Therefore, the deterring party sets up penalties for failing to respond in the way threatened. This can be done by issuing statements and binding oneself to follow through or by putting down resources to defend. ${ }^{6}$ If the deterring party has nothing at stake in following through on its threat, then 
once the other party has acted, it would be illogical to go through with the threat. To ground this example, if the United States announces it might defend Taiwan, but might not, then China will be more likely to attack, knowing that then the United States will lose nothing for not following through on its threat.

There is a special case that Schelling makes, the "threat that leaves something to chance." In this case, the deterring party puts forward what the chance is that it will follow through on its threat. ${ }^{7}$ In this case, the deciding mechanism still has to be outside the hands of the deterring party. The point of leaving it to chance is to lessen the overall expected cost of the deterrent. However, it must be left to real chance and the decision to fulfill the threat must be wholly outside of the hands of the deterring party. ${ }^{8}$ If the decision is in the hands of the deterring party, then the same problem arises of there being no incentives to fulfill the threat.

Schelling does offer one glimmer of hope to those who support the ambiguous nature of the US response. This is because there is always a chance that, despite what either side may wish, escalation may occur. Therefore, any move that raises the chance of escalation can act as a deterrent. In this way, it is possible for the US to make an effective deterrent by the level of its rhetoric or the level of its shows of support to Taiwan, if it seems that the actual decision of going to war could happen despite the potential negative payoffs for US policy makers. ${ }^{9}$ The actions by President Clinton in 1996, when he sent US carrier groups into the strait, exemplify this from of threat. Technically, the decision to start military conflict was still his own, the chance for accidental or inadvertent escalation went up dramatically between the US and the PRC, forcing the PRC to lower its bellicosity. Also, this is an example of how, while still being 
ambiguous about future actions, past Presidents have been able to use actions as well as words to prove their commitments.

However, Schelling's work suffers from the obvious flaw of only being applicable to two-party games. In the entire book, there is no discussion of three party games. While the system could be broken down into three two-party games (US-PRC, US-ROC, PRC-ROC), it would ignore the strong interest each party has in what the other two parties do. An example of the problems in a three-game model (as opposed to a onegame three-party model) is the PRC's opposition to ROC weapons purchases from the United States. Splitting up the system into three two-party games would obscure that, and so a three-party deterrence theory is needed.

A subsection of deterrence theory has been created to discuss three-party games like this. Extended deterrence is the concept of deterring one country from attacking an ally, in contrast to traditional deterrence which is only to protect one's own country. In extended deterrence, there are two bigger powers and one lesser power, and the smaller state is aligned with one of the bigger powers. The smaller state is the Protégé, its ally is the Defender, and the other power is the Challenger. The game theoretical models then try to examine how to keep the Challenger from attacking (or, in some cases, even making demands on) the Protégé. Many scholars have viewed the US-PRC-ROC triangle merely as an example of extended deterrence, with the US as Defender, the ROC as Protégé, and the PRC as Challenger. These scholars have then gone on to make recommendations based on this. ${ }^{10}$

However, much of this scholarship ignores the ability of the ROC to be an actor in its own right. The focus of much of the extended deterrence literature is purely on how the US and the PRC should communicate and what kinds of threats that the US can make 
to deter the PRC. ${ }^{11}$ Trying to prevent the ROC from provocation is mostly ignored in this literature, and it is assumed by some that any deterrent threat that takes into account the actions of the ROC is inherently not credible. ${ }^{12}$ Since the main point of contention in the referendum crisis was a deliberately provocative move on the part of the ROC President, any theory that ignores the actions of the Protégé is inherently limited in discussing this particular crisis.

This is not to say that no research has been done into the importance of the Protégé in extended deterrence. Zagare and Kilgour developed the "Tripartite Crisis Game" to explore the different options available to the three parties in extended deterrence once a crisis has been initiated, depending on the different natures of the participants. ${ }^{13}$ The Tripartite Game actually has as a condition that the Protégé is completely capable of acting on its own, and the actions and motivations of the Protégé are inherently necessary for understanding the overall course of the game. This makes it superior to most forms of "extended deterrence".

Even Zagare and Kilgour's analysis offers little help in unraveling the Taiwan Strait, however. One of their key assumptions for analysis is that the Protégé puts the status quo above all other possible resolutions. Their reasoning is that no Protégé would want to provoke any kind of conflict that would put them in debt to the Defender or could lead to (possibly disastrous) conflict with the Challenger. ${ }^{14}$ This implies that the Protégé could not fight back effectively against the Challenger without the aid of the Defender. It is a matter of debate whether the ROC would even need US help to fight off an invasion by the PRC. ${ }^{15}$ It seems that the ROC leadership has a definite preference for changing the status quo, since they made provocative statements. It is admittedly difficult to induct preferences based on policies and actions, and it is possible that the ROC actions were 
instead to preserve the status quo. However, in the absence of similar probing from the PRC, this seems unlikely.

Some other scholars have instead attempted to create a theory of "dualdeterrence." Dual-deterrence is an attempt to keep both sides from acting against the other. ${ }^{16}$ Using the language of dual-deterrence eliminates the extended-deterrence and Tripartite-Crisis Game problem of ignoring the actions and motivations of the ROC. However, the dual-deterrence literature is still quite small and contradictory. Those in favor of "strategic ambiguity" cite dual-deterrence as the only possible way for the US to navigate the zero-sum wishes of both the PRC and the ROC, ${ }^{17}$ while many of those opposed to strategic ambiguity say that dual-deterrence is too delicate to be maintained over the long term, and that a long term solution is needed. ${ }^{18}$ Extensive work needs to be done on expanding this into a fully rigorous theoretical model. Until that time, however, the theory is of limited utility.

Also, in a technical sense, despite the prevalence of the term in describing the USROC relationship, the US is not engaged in deterrence with the ROC. Every threat directed at the ROC is not a threat to attack or damage the ROC, but instead to merely remove support from the ROC in the case of a PRC attack. This threat is strong enough that many other scholars have considered it to be a form of deterrence, ${ }^{19}$ especially in that US support is often considered to be essential to the survival of the ROC state. In the classic sense, however, it is not a threat to engage in military action against the ROC, which is essential for defining deterrence. Schelling wrote that deterrence is concerned with influencing the decisions of others by influencing their expectations of future behavior. ${ }^{20}$ In this sense, the US threat to not fight a PRC attack on the ROC would be aimed at deterrence in the broader sense, and follows the same logic. 
Despite some of these problems, deterrence theory cannot be completely thrown away, because it is the essence of what the US is trying to accomplish. As the US seeks to keep both the PRC and the ROC from fighting in the Taiwan Straits, its policy is to combine threats and promises. Therefore, in order to understand US policy and its usefulness, deterrence is essential. The insights offered by deterrence theory, while incomplete, must still guide policy makers as they struggle to keep these two adversaries from the brink, and remains the only theory that gives recommendations on such a course of action. Therefore, while keeping in mind its limitations, deterrence in all of its permutations must be considered in analyzing US policy.

Because it is incomplete, another theoretical component should also be added. The concept of "strategic triangles" is much more useful for examining the state of affairs and the relationships in the Taiwan Strait. The theory of strategic triangles, rather than looking strictly at how to prevent a Challenger from attacking a Protégé, instead looks at alignment patterns and shifts in diplomacy among three states. While this is less rigorous than the strict game analysis of most deterrence theory, it allows for all three actors to try changing the status quo. It also is able to look beyond an immediate crisis and make predictions about the long-term viability of a particular partnership and how a situation like Taiwan might change on a structural level.

A strategic triangle requires that each of the actors recognize the importance and autonomy of the others. ${ }^{21}$ By these criteria, the US-PRC-ROC triangle qualifies. Once that has been established, it is then important to understand the current status of relationships in the triangle. Based on that, there are four different triangle structures, and six different positions a state can be in. The structural possibilities are "ménage-atrois," "romantic triangle," "marriage" and "unit veto.,"2 The ménage-a-trois is when all 
three players have good relations with each other (and thus are all "friends"), and the "unit veto" is when all three have contentious relations (and thus are all "foes"). The romantic triangle is when two states that dislike each other ("wings") have good relations with the third ("pivot"); the marriage is when two states that like each other ("partners") have strained relations with a third ("pariah"). The current triangle fits the model of a "romantic triangle," in that the US has good relations with both the PRC and the ROC, but the two feel enmity towards each other.

It must be noted that, within strategic triangle theory, it is usually assumed that every state seeks to maximize its own friends and minimize the friends everyone else has, though maximizing friends is more important than minimizing possible collusion. ${ }^{23}$ Thus, the ranking of positions is pivot, friend, partner, wing, foe, and lastly pariah. In theory then, the US should be enjoying its role as the pivot between the PRC and the ROC and should be working hard to gain maximum concessions from the two. ${ }^{24}$

However, the US might not be willing to maintain this role. If the US is willing to play the part of a pivot, it would make sense for the United States to tack back and forth between the two other actors consistently in order to maximize gains and maintain the position. But, if the US is unwilling to do this, then it will seek to escape the position, either by getting the PRC and ROC to work together and form a "ménage-a-trois", or by "marrying" one of the two regimes. ${ }^{25}$ Traditionally, the ménage relationship is impossible to maintain, and marriage is the most likely outcome, according to the literature. Historically, it is more common for a pivot to "marry" the weaker wing in the triangle, in order to contain the stronger wing. Moreover, some have seen evidence of incipient nuptials between the US and the ROC. ${ }^{26}$ However, until that time, the unwilling pivot will tack back and forth and try to form compromises between the two "wings". 27 
If this is the situation, then it would be revealed more by the actions of the United States than by the actions of the other two. However, this system also makes predictions about the actions of the two wings. From the perspective of each wing, it is advisable to break up the relationship between the other two players, or else to form their own amicable relationship. In the case of a willing pivot, it could be useful for the two wings to work together towards an amicable relationship in order to stop the flow of concessions to the pivot. This would lead to a demotion of the pivot to a friend, and the elevation of the wings to friends. A willing pivot would work hard against this, in order to maintain its position and concessions. However, more often than not, that enmity cannot be overcome, and instead the wings work to cleave to the pivot and break the pivot's relationship with the other wing. This is especially true in the case of an unwilling pivot, as it can be assumed that the pivot has already been working to create a ménage situation and end the constant positioning to keep the wings happy.

With all of this in mind, the "triangle relationship" model is also useful for examining the US response to both the referendum crisis and the 1996 crisis. This is the only full model that gives the ROC some degree of autonomy as an actor, which is essential given the central role the ROC played in instigating the most recent crisis. Moreover, unlike all deterrence theories, the strategic triangle model allows for better understanding of possible futures for the Taiwan Straits and for the three different bilateral relationships.

Strategic triangle analysis is not often used to explain short term crises, because it more closely investigates long-term trends in relationships. This is useful, however, in determining whether the crisis had a strong impact on the relationships, and whether relationship-based thinking influenced US policy. Some scholars have suggested that the 
referendum crisis helped to reverse a slide toward a marriage between the US and the ROC, returning the system to a romantic triangle. ${ }^{28}$ Moreover, strategic triangles can be used to explain why a given state would be more inclined to use inducements or would be afraid to issue threats. This was clearly the case with this crisis, with the US afraid to hurt its relationship with either side while the other two slung abuse back and forth repeatedly and called on the US to help.

Both theoretical perspectives must be employed. In order to understand the ability of the US to achieve its interests, deterrence must be used, but in order to understand the structural elements of the dynamics, strategic triangles are essential. Elements of both combine to show how the US, afraid of offending either party, instead engaged in cheap talk designed to placate all parties. This cheap talk, while ambiguous, was enough to maintain both relationships, but did nothing to actually deter either actor. This is the meaning of "cheap ambiguity," and can only be understood with both theories. 


\section{CHAPTER III}

\section{HISTORY OF THE TAIWAN STRAIT ISSUE}

Before examining the referendum crisis, it is important to have an understanding of how the status quo came to be. Without a sense of history, the different perspectives on the crisis will be unintelligible.

Prior to 1624 , the population of Taiwan was predominantly aboriginal, with affinities to both Malayo-Polynesian and mainland Chinese groups. ${ }^{29}$ At that time, Chinese, Japanese, Spanish, English, and Dutch traders all began to settle on the island, making it a commercial hub. ${ }^{30}$ Eventually, the Dutch took control, though they were soon forced out by the "pirate" Zheng Chenggong. ${ }^{31}$ It was not until 1683 that the island of Taiwan was brought under the rule of the mainland, imperial government. ${ }^{32}$

The Qing dynasty worked hard to prevent the full colonization of Taiwan, fearing that it would lead to more rebellions and trouble. ${ }^{33}$ They forbade the colonization of families, allowing only seasonal, male workers. People migrated anyway, and attempts to be even stricter led to the very rebellions the Qing feared. ${ }^{34}$ After that, China began the process of turning Taiwan into a province. ${ }^{35}$

At the end of the Sino-Japanese War of 1894-5, however, China was forced to cede Taiwan to Japan. The Japanese suffered periodic revolts on the island, but they also found accommodationists willing to work with them. ${ }^{36}$ While the Japanese occupation 
was brutal, it nevertheless built on Taiwan a stronger industrial base and a more educated populace than existed on the mainland. ${ }^{37}$

After World War II, the Allies, including the US, forced the return of Taiwan to China. The Taiwanese were somewhat ambivalent about the return. They had gone through fifty years of tranquility, relative to China, in that Taiwan had not experienced the Chinese Civil War and had not been a battlefield for World War II. ${ }^{38}$ At the same time, Japanese rule had been harsh, and most were ready to rejoin the "motherland," despite their misgivings. The Republic of China, as the internationally recognized government of China, took control. However, when they did so, they were considered as cruel as the Japanese. To many Taiwanese, the Kuomingtang (KMT), who ruled the ROC, lacked what few virtues the Japanese had, such as competence and efficiency. ${ }^{39}$

While the Taiwanese were upset at the KMT, and engaged in public protests, the problems were not insurmountable until the end of the Chinese Civil War, when the KMT lost to the Chinese Communist Party (CCP). In December of 1949, the KMT fled to Taiwan as their last holdout. While the US had supported the KMT during the Civil War, the sheer incompetence and corruption of the KMT led to the US waiting until the war was over before recognizing either government. ${ }^{40}$ Mao Zedong proclaimed the birth of the People's Republic of China (PRC), and announced that the CCP was now the legitimate ruler of China. The US did not immediately recognize the PRC, but showed willingness to do so in the near future, depending on how the situation progressed. This was the earliest sign of ambiguity about the Taiwan issue.

While waiting for the seemingly inevitable attack by the Communist forces, Chiang Kai-shek, the leader of the KMT, took the opportunity and time afforded him by the Taiwan Strait to set about reorganizing and reforming his government. He felt that it 
was the only chance he had of gaining support from the US, without which his regime was sure to fall. ${ }^{41}$ Though they won some victories defending some of the smaller islands around Taiwan, the KMT did not have much hope. ${ }^{42}$

Chiang and his regime were the biggest beneficiaries of the Korean War, which broke out in June, 1950. The United States ordered the Seventh Fleet into the Strait in order, officially, to prevent either side from starting hostilities while the US was focused elsewhere. ${ }^{43}$ This helped to keep Taiwan firmly in KMT hands. After the Korean War, the US looked to the ROC as a strong ally in containing Communism, and Chiang pledged that the island would be "an unsinkable aircraft carrier" for American forces. In 1954, a peace treaty was signed between the US and the ROC, formalizing that agreement. ${ }^{44}$

However, the two sides were not in perfect agreement about everything. Chiang, in particular, wanted the US to help him retake the mainland. ${ }^{45}$ The US had no intentions of getting into a war with China, and thus restrained Chiang, even as the PRC was attacking a few of the ROC's furthest islands. ${ }^{46}$ Strategic ambiguity began, with the US pledging to defend the ROC from attack, but also restraining the ROC from attacking the PRC. Issues of de jure independence were not considered, because neither the US nor the KMT leadership was in favor of it.

This period is usually considered a "marriage" between the ROC and the US, even though the relationship was still troubled. It was obvious that the US and ROC were partners allied against the "pariah," the PRC.

In the 1970s, however, US policy towards the Taiwan problem changed dramatically. Seeking a strong ally against the Soviet Union, the US opened up to the PRC. In order to do this, the US had to cease recognizing the ROC as the legitimate 
government of China. ${ }^{47}$ One consequence of this was that the US ended the defense treaty with the ROC, and removed American troops from Taiwan.

However, while US presidents were pushing for closer relations with the PRC, Congress pushed the other way. The ROC had several prominent allies in Congress, who pushed through the Taiwan Relations Act. The Taiwan Relations Act said that the security of Taiwan was of grave interest to the US, and that the US would sell arms to the ROC to provide it with "sufficient self-defense capabilities." 48 This was far short of the security guarantee that had existed, but it did provide some assurance that the US would stay involved. The extent of this involvement, though, was very ambiguous. It still seemed that the US was creating a "marriage" to the PRC, in order to balance against the USSR, while mostly ignoring the ROC. ${ }^{49}$ At the very least, the old marriage was gone and the triangle began.

Throughout this time period, the ROC was undergoing strong changes. Chiang Kai-shek died in 1975, and his son took over in 1978. His son began the process of political liberalization, though it was slow and uneven. ${ }^{50}$ Congressional pressure helped the process along as well.

In 1988, Chiang Ching-kuo, Chiang Kai-shek's heir, also died. He was succeeded by Lee Teng-hui, the first native Taiwanese to hold the top job within the KMT. Under Lee, the democratization begun by Chiang Ching-kuo sped up dramatically. Within six years, all of the institutions of democracy were in place, and the ROC began preparations for its first free elections. ${ }^{51}$

These changes in the ROC took place in a steadily changing relationship between the PRC and the US. The PRC had protested the US policy of continuing to sell weapons to the ROC as a violation of the terms of recognition. The Reagan administration agreed 
to lower the amount of arms sold to the ROC, though this agreement was never enforced. $^{52}$

Then, the Cold War ended. The strategic necessity of close relations with the PRC dissolved. At the same time, American opinion was turning against the PRC, after the Tiananmen Square incident of $1989 .^{53}$ In 1992, then-candidate Bill Clinton ran on a platform that included opposition to granting Most-Favored Nation status to the PRC, based on its human rights record. ${ }^{54}$ He signed an executive order requiring progresss on human rights by the PRC for MNF in 1993. ${ }^{55}$ Soon, Clinton was tacking back towards the PRC, in a dance that would take up his entire presidency, and ended the link between MFN and human rights in $1994 .^{56}$

In 1995, Cornell University invited ROC President Lee Teng-hui to America to receive an award. The PRC was adamant that the US should not allow President Lee into the country, and Clinton agreed to keep him out. Congress then passed a non-binding resolution, by an overwhelming margin, to allow Lee to visit. Clinton acquiesced, at least in part to prevent Congress, with their veto-proof majority, from making it a more formal visit. ${ }^{57}$ The PRC felt they had been betrayed, and responded by recalling their ambassador and postponing several important talks between the US and the PRC. ${ }^{58}$

Then, in 1996, as the ROC prepared for its first presidential election, the PRC began firing missiles north and south of Taiwan. It was widely assumed that the PRC was trying to influence the ROC elections, to prevent Lee Teng-hui from being elected. ${ }^{59}$ The US responded by sending two aircraft carrier groups to the region, while at the same time making concessions to the PRC in other areas. ${ }^{60}$ In 1998 , Clinton went so far as to declare the "Three Noes," which were that the US did not support a "two China" or "one China, one Taiwan" policy, did not support Taiwanese independence, and did not support 
allowing the ROC into any international organization for which statehood was a requirement. $^{61}$

George W. Bush's presidency offered a strong contrast to that of Bill Clinton's. George W. Bush made it clear very early in his presidency that the US would do "whatever it takes" to defend the island of Taiwan. ${ }^{62}$ The Bush Administration tried to regularize weapon sales to the ROC, including some weaponry previously considered too "offensive," such as Kidd-class destroyers and diesel submarines. ${ }^{63}$ This was seen by some as an abandonment of the PRC and an attempt to recreate the marriage of the early Cold War.

After the attacks on the US on September 11,2001, the US tried to reconcile with China in order to get China's help on North Korea and the War on Terrorism. ${ }^{64}$ This forced the US to revalue its relationship with the PRC. The Bush administration began to work closely with China, and recreated the "romantic triangle" they had earlier rejected. With an ideological affinity for the ROC and a practical need for PRC cooperation, the US was back in the position of an unwilling pivot between the PRC and ROC. This was the environment at the time that Chen Shui-bian began calling for referenda to help promote Taiwanese sovereignty.

This history has led to three different understandings of the current status of Taiwan. The PRC sees separation, with an acknowledgement that Taiwan is a part of China, as the status quo, because the US and the ROC constitution both agree that Taiwan is a part of China. The PRC sees Taiwan as a part of the lost Qing Empire, and sees the Taiwanese people as members of the Chinese nation. On the other hand, the current ROC leadership sees de facto independence as the status quo and Taiwan as a separate nation. This leadership draws on the fact that Taiwan, for most of its history, 
has not been under the full control of the Chinese government. For its part, the US just sees the separation as the status quo, and opposes efforts both to end forcefully the separation and to declare Taiwanese independence. This understanding does not try to declare anything about the nationality of the Taiwanese, but instead looks back to the end of the Chinese Civil War and the separation that followed.

It is, in part, these competing narratives and understandings that cause much of the tensions among the three actors, as each seeks to defend its actions by declaring that they support the status quo, even when the other actors find the actions threatening. 


\section{CHAPTER IV}

\section{POLICY AND ACTION: ANALYSIS OF POLICY AND HOW IT AFFECTED THE OUTCOME OF THE CRISIS}

The concept of strategic ambiguity is one that has often been used to describe US policy towards the overall Taiwan Strait situation as well as the referendum crisis itself. The literature on strategic ambiguity is very conflicted, with scholars often debating the usefulness of the concept. It is important to note that strategic ambiguity is, officially, not ambiguity about American intentions or desires, but only ambiguity about what would trigger US intervention. ${ }^{65}$

Many would like for the US to drop ambiguity. However, it is often forgotten that the ambiguity is written into the documents that make up US policy. The most important documents for US policy are the three joint Sino-US Communiqués and the Taiwan-Relations Act. These documents are very vague, and where they are explicit, they are contradictory.

Just as the historical background is necessary, it is also necessary to understand what Richard Bush referred to as the "sacred texts" of the US-PRC-ROC relationship." These are the statements of US policy made by successive US administrations. While often referred to by all parties, the actual text of these statements is often ignored, due to their contradictory nature. The PRC prefers to ignore the Taiwan Relations Act, the ROC prefers to ignore the Joint Communiqués, and the US tends to pick and choose from them 
based on the situation it is facing at the time. These documents are important because they define the major limits of American policy. While any administration could unilaterally back out of any of these agreements, it would be such a great blow to American prestige and trustworthiness that it would be extremely unlikely.

The first of these texts was the "Shanghai Communiqué on the Taiwan Issue." This agreement was reached on February 27, 1972. The communiqué, obviously, did not solve the dispute, but the United States and the PRC both made their respective positions clear. The US acknowledged that both the people on the mainland and on the island agreed that there was only one China, and the US did not challenge that position. ${ }^{67}$ This was not an explicit agreement with the PRC position, but instead merely acknowledged what the PRC claimed and did not oppose it. The US also espoused its interest in a "peaceful settlement" of the Taiwan issue, and thus agreed to remove its troops from Taiwan as the tension in the Strait diminished. ${ }^{68}$ This was in stark contrast to the PRC's position that the Taiwan issue was a purely domestic affair, in which no other state had the right to interfere, but it did establish that the US was interested in a long term solution.

The second communiqué was issued January 1, 1979. In this, the US acknowledged that the PRC was the sole government of China, and both states affirmed that they were not interested in achieving hegemony in the region. The US also again acknowledged the PRC "One-China" policy, without explicitly endorsing it. ${ }^{69}$ In accompanying statements, however, the US maintained that it would continue to have unofficial relations with the people of Taiwan. The US also agreed to remove its military personnel from Taiwan, while at the same time reiterating its interest in the peaceful resolution of the problem and the continuation of arm sales to the ROC. ${ }^{70}$ 
Congress, after what it felt was the "abandonment" of the ROC, passed the "Taiwan Relations Act" on April 10, 1979. The TRA maintained that it was the policy of the United States to "preserve and promote extensive, close, and friendly commercial, cultural, and other relations between the people of the United States and the people on Taiwan" while also maintaining similar ties with the people on the China mainland. ${ }^{71}$ It also said that any attempt to determine the future of the island by non-peaceful means would be "of grave concern" to the United States, and that the US would continue to provide "arms of a defensive character" to Taiwan. ${ }^{72}$ Lastly, the TRA established the "American Institute in Taiwan," to replace diplomatic contacts. ${ }^{73}$

It is important to note that this was in some ways stronger and in some ways weaker than the previous Defense Treaty. The Treaty obligated the US to act to "meet the common danger," whereas the TRA said that boycotts, embargoes, use of force, or coercion were all of grave concern to the US. ${ }^{74}$ On the other hand, it changed the policy from a mutual defense pact to merely being an expression of potential "grave concern." 75

The arms sales part of the TRA was then contradicted by the next major statement. On August 17, 1982, the last US-PRC Joint Communiqué was signed. In it, the US and the PRC agreed that the PRC was the legitimate government of all China, and that both states would respect the territorial integrity of the other. ${ }^{76}$ At the same time, the US agreed not to increase the quality or quantity of arms sold to the ROC, with the intention of slowly reducing the amount of arms sold. ${ }^{77}$ This was eventually ignored, and arms sales continue to this day, some much stronger than sold in previous administrations. However, it is official US policy to shrink them.

The contradictions in these policy statements are obvious. The US promised to help the ROC defend itself and to preserve peace, and at the same time promised not to 
interfere with internal Chinese matters. The US acknowledged the PRC as the sole government of China, and at the same time maintained an unofficial, complete separate embassy on Taiwan. Supplying weapons to an armed subnational group would ordinarily be interpreted as interference in another nation's internal affairs. As the US recognizes Taiwan as part of "one-China," even if it does not necessarily recognize PRC sovereignty over the ROC, it is obvious that the US is thus supplying weapons to an armed subnational group. Moreover, locating an embassy, even if unofficial, within an armed subnational territory sends a strong message that the US does not believe as strongly in PRC sovereignty as the US proclaims.

Moreover, which of the "sacred texts" should have pre-eminence is a matter of debate. The PRC often maintains that the TRA should not have any weight, as it is a matter of "domestic legislation," and thus cannot apply to international agreements. This, to most Americans, is a misunderstanding of the US system of checks and balances. To most people in the US, a law passed by Congress and signed by the President has much more strength than and would supersede any agreement between the President and a foreign head of state. A treaty would be considered the law of the land, but none of the communiqués have been submitted for ratification by the Senate as treaties. This disagreement as to the supremacy of the TRA or the communiqués continues to cause problems between the PRC and the US. This became explicit during the referendum crisis when the PRC repeatedly asked the Bush administration to ignore the TRA.

Repudiating the TRA was impossible, and showcases the limits on US administrations. Such an act would require either for Congress to revoke it, or else it would provoke an American constitutional crisis. As far as the US is concerned, these are the limits of possible action. The US cannot act in ways that are deliberately against 
these "sacred texts," because it would either mean an internal crisis or an end to constructive relations with the PRC. These policy concerns must be remembered as the crisis itself is analyzed.

With this understanding of the foundations of American policy, the referendum crisis can also be understood. The referendum crisis began in October of 2003, when President Chen Shui-bian of the ROC began calling for referenda in Taiwan to address nuclear power policy, the size of the legislature, and the ROC's efforts to join the World Health Organization. ${ }^{78} \mathrm{He}$ even went so far as to say that the ROC was an "independently sovereign" country. By this, he meant that the sovereignty of the ROC was independent of the PRC, even if the island of Taiwan was not independent of China. Thus, the ROC was not responsible to the PRC for its own policies. He did stop short of calling for complete independence, but many in his pro-independence base rallied to support these moves.

Chen then called for legislation to allow for referenda in Taiwan. The oppositioncontrolled legislature, known as the Legislative Yuan, was strongly opposed to any measure that would allow referenda on the island. The opposition party, the KMT, thought it would be a needless provocation of China, while Chen and the Democratic People's Party (DPP) said it was necessary for Taiwan to be truly democratic. Chen and the DPP wanted the ability to alter the ROC Constitution through referenda as well, claiming that the Constitution of the ROC was hopelessly out of date and deeply undemocratic. $^{79}$

The PRC responded that any legislation that allowed unrestricted referenda would be seen as an attempt to declare independence. The PRC also called on the US to change policy and to support fully the PRC and to stop supporting "separatists." 
the PRC reiterated its demand that Washington stop selling sophisticated weaponry to Taiwan. ${ }^{81}$ Beyond that, the PRC officials made it explicitly clear that any attempt at $d e$ jure independence would be treated as a declaration of war. ${ }^{82}$

While the referenda were still only hypothetical, the US did little about them. The US stated it was opposed to any referendum law that would allow for votes on Taiwanese independence, but otherwise was unconcerned about it. ${ }^{83}$ This shows the extent to which the US was not paying attention to events in the Taiwan Straits. The PRC had already made clear that there were many actions it would consider as steps towards independence, and Chen had made just as clear that he was intent on pushing toward independence. The US supported neither side, but merely came down against the most extreme position that the ROC might hold. This suggests that the US was either unaware of the danger ahead, or hoped that the problems would be resolved without US help.

When the time came for a vote on the referendum bill, the KMT and its allies, seeing the gain in the polls that Chen Shui-bian had made, pushed their own version of a referendum bill. This was a reversal from their previous, staunch opposition. It also allowed them to limit the bill sufficiently so as to not offend the PRC. The new law explicitly stated that the name of the country, the flag, the anthem, and the official territory of the ROC could not be put to a referendum. Moreover, altering the Constitution would require the support of three-quarters of the members of the Legislative Yuan in order to go before the people. These were all stipulated by the KMT. The DPP and its allies were allowed a single concession, which was the ability of the Executive Yuan and the President to put forward a referendum on national security when the sovereignty of the ROC was threatened by an outside power. ${ }^{84}$ 
To some degree, this pacified the PRC. However, the inclusion of the "defensive referendum" clause was still problematic, from its point of view. The PRC claimed that this was merely a hidden way for the President to call for an independence referendum. Moreover, they worried that any form of referendum ability would cause independence activists to push for a greater "Taiwan independence awareness," and an eventual push to change the law to allow for independence. ${ }^{85}$ However, the statements were viewed as less overtly threatening than many that had been made prior to the passage of the bill. ${ }^{86}$

This was followed by a brief bit of calm. Then, Chen Shui-bian started a discussion about invoking the "defensive referendum" clause. At the time, China had roughly 450 missiles pointed at Taiwan, and had accelerated production and deployment. ${ }^{87}$ Also, American analysts had inferred that the PRC was hoping to be able to coerce the ROC into reunifying, by being able to attack and conquer Taiwan before the US would be able to help. ${ }^{88}$ It is important to note that the American analysts feared PRC use of coercive diplomacy, rather than an actual attack. In any case, President Chen said that the missiles pointed at Taiwan constituted enough of a threat that the "defensive referendum" clause could be invoked, and on December 5, 2003, he declared that such a referendum on the missiles would be held concurrently with the Presidential election. ${ }^{89}$ His office was also quick to assure the world that the issue of Taiwanese sovereignty, and thus any notion of independence, was not included in the referendum. ${ }^{90}$

It is debatable as to whether the forces across the Strait constituted the kind of threat that the Legislative Yuan had in mind when they passed the referendum law. While the PRC had never ruled out the possibility of an armed attack, few observers anticipated PRC use. However, the legislation was written to protect against threats against the "sovereignty" of the ROC, which the official and continuous state of 
hostilities with the PRC, especially given its intense military build-up, arguably constituted.

When Chen announced his plans to hold a referendum, the officers in the PRC's military, the People's Liberation Army, announced that Chen Shui-bian would be held responsible for war breaking out and eventually treated like a war criminal. This was before any announcement of the nature of the referendum. These officers also accused Chen Shui-bian of pushing the Strait to the "brink of war." "91 They also laid out all of the "prices" the PRC was willing to bear, including boycotts of the Olympic games, recession, military casualties, a loss of foreign investment, and deterioration of foreign relations.

US Secretary of State Colin Powell issued an ambiguous statement that both sides should "be careful about what they say," and needed to "realize where their interests are." ${ }^{92}$ At the same time, the ROC was lobbying hard for American approval of the referendum as an expression of Taiwanese democracy. ${ }^{93}$ Chen also stated that, rather than trying to increase the chances of war, he was actually hoping to decrease them, by focusing international attention on PRC aggression. ${ }^{94}$ An influential advisor to the PRC on Taiwan issues, Xu Shiquan, countered that Chen could ensure that Taiwan was never attacked by promising to never declare independence. ${ }^{95}$

Here, the different positions and favored end situations were clearly laid out. The PRC said that negotiations could only be conducted if the ROC accepted the "one-China" principle. The ROC was unwilling to negotiate until after military options were off the table, which the PRC refused to do until the ROC accepted the one-China principle. At the same time, the US was left merely to counsel caution and attempt to keep events under control. This would continue to be the US position throughout the conflict. 
Then, just before he was supposed to meet with PRC Prime Minister Wen Jiabao, US President Bush issued a warning to ROC President Chen that the US would not necessarily help the ROC if it declared independence. Some in the administration labeled it a "dropping of ambiguity," giving clear limits to the circumstances in which the US would get involved. ${ }^{96}$ However, the limits given were not new. The US had always opposed de jure independence for Taiwan, and had also always opposed an unprovoked attack on Taiwan, and so the new clarity did not clear out any of the grey area that existed. Therefore, this did nothing to change perceptions on possible American intervention.

A few days later, on December $10^{\text {th }}$, the President of the US came down more decisively on the PRC side. After meeting with Wen Jiabao, Bush gave a speech declaring that he opposed Chen's willingness to change the status quo in the Taiwan Straits unilaterally. ${ }^{97}$ The US also cancelled defense talks and a computer war simulation with the ROC military. ${ }^{98}$ However, the PRC continued to demand other concessions as well, such as an end to arm sales to the ROC and a commitment to non-interference in the issue.

Perspectives were split in the US, and not along normal ideological lines. Many neoconservative think-tanks, usually supporters of the Bush administration, joined with the Washington Post and Democratic members of Congress to criticize the President's support for "the world's largest dictatorship." 99 House Democratic Leader Nancy Pelosi released a press statement urging Bush to support Taiwanese democracy and the right of the Taiwanese to vote on referenda. ${ }^{100}$ The New York Times, on the other hand, while a long time critic of the Bush administration, supported its efforts to make the two sides look at the situation rationally. ${ }^{101}$ 
Reaction within the ROC was mixed as well. The DPP and Taiwan Solidarity Union (TSU), together known as the Pan-Green Coalition, supported President Chen and protested President Bush's comments, though they also acknowledged that it in no way differed from previous US policy. ${ }^{102}$ The opposition Pan-Blue Alliance, made up of the People First Party and the KMT, on the other hand, explicitly called for Chen to drop the referendum entirely, blaming him for the rising tensions and worsening relations with the US. ${ }^{103}$ They explained that the statement was merely US policy, and that Chen's provocations would only hurt the ROC.

What most officials in all governments were missing, though, was the way the statement did differ. Previous pronouncements, including the one by Colin Powell, always tried to maintain that the US acted as a fair balancer between the two sides. However, by standing explicitly next to Premier Wen, Bush made it seem that the US was siding with the PRC against the ROC. Moreover, it came merely as a result of a proposed referendum, which did not come near the limits that the US had previously made explicit. The ROC was not declaring independence, nor changing its constitution or its name. The sense of shock felt in the ROC was genuine.

However, at the same time, it would turn out to be the strongest stand that the US would take against the ROC. The canceling of the defense talks and the computer simulation would be the only penalty that the US would impose on the ROC for its provocations. By imposing a cost at first, and then not following through, the US either played all of its cards at once, or else was incapable of affecting the ROC. This is not conducive to a strong deterrent, but it suggests that the US was strongly worried about weakening the strong relationship shared by the US and the ROC. 
Despite the difference of opinion within the ROC, Chen continued on with plans for the referenda. Moreover, both the ROC and the PRC began vying for international support for their positions. On December $12^{\text {th }}$, the deputy secretary-general of the National Security Council of the ROC, Ko Cheng-heng, used his pre-arranged trip to Washington to explain the ROC's stance on the referendum to US authorities. ${ }^{104}$ President Chen also explicitly, if rhetorically, asked PRC President Hu Jintao to explain to the world why the PRC could not renounce the use of force or redeploy the missiles away from the Taiwan Straits. ${ }^{105}$ Chen later made a speech in which he tried to explain that his own views and President Bush's were completely in agreement. ${ }^{106}$

At the same time, the PRC Premier, Wen Jiabao, went on a tour of the world to drum up support for the PRC position. Wen Jiabao, after leaving the US, went to Canada, Mexico, and Ethiopia, and also visited the China-Africa Cooperation Forum. ${ }^{107}$ At the same time, the Vice-Chairman of the Central Military Commission went to Russia to strengthen ties, and came away saying that Russia also opposed the ROC referendum. ${ }^{108}$

The rhetoric between the two sides changed in tone. The PRC began a campaign to seem more conciliatory towards Taiwan and the ROC took a more militant stance. While still referring to the referendum as a "serious provocation," the State Council Taiwan Affairs Office spokesman Li Weiyi called for direct air flights between Taiwan and the mainland for the duration of the Spring Festival and supported ROC inclusion with the PRC delegation to the WHO. ${ }^{109}$ In contrast, while the ROC made some effort to convince the PRC that its referendum was not actually provocative, ${ }^{110}$ the ROC military also made clear that it would respond to any PRC military action "in line with relevant combat regulations." 111 At the same time, Chen announced that he would revoke his 
"Five Noes" pledge in the event of the PRC attacking or threatening the ROC, and called on the PRC to move its missiles and swear not to attack the ROC. ${ }^{112}$

The ROC kept up its PR campaign, with the ROC Vice President Annette Lu making additional speeches ${ }^{113}$ and the spokesman for the Executive Yuan warning his compatriots that the soft approach by the PRC was merely a cover for the missiles deployed against them. ${ }^{114}$ In contrast, for a week, the PRC government made no overt mention of the affair in the press, until December $31^{\text {st }}$ when the spokesman for the Taiwan Affairs Office, Zhang Mingqing, blasted Chen for being an immoral separatist. ${ }^{115}$

With these events, it is apparent that both the PRC and the ROC were interested in different audiences. The PRC appealed to the world as a victim. This may seem odd, in that the PRC is much larger and is considered much stronger, both economically and militarily, than the ROC. The PRC proclaimed, however, that it was the ROC that was trying to change the status quo. At the same time, the ROC's strategy was not to back down and to proclaim instead that it was only responding to the PRC's own attempts to change the status quo.

Clearly, the ROC and PRC each saw different actions as attempts to change the status quo. Since the ROC sees the status quo as de facto independence, the use of coercive diplomacy (in the form of the missiles across from the island) is an attempt by the PRC to change the status quo. On the other hand, the PRC sees the current situation as one of overall acceptance of the "one-China" policy, and any attempt to alter that changes the status quo. Thus, the attempt by the ROC to push away from the PRC or to treat the PRC as a separate nation was an attempt to change the status quo. Each side decided to make its case to world opinion. 
Through these events, the US government did not say much. On December $31^{\text {st }}$, the US State Department Deputy Spokesman Adam Ereli again voiced US opposition to the referendum on the grounds that it could lead Chen to have a referendum later to change the status quo. ${ }^{116}$ However, the administration was also clear that it would not impede other parts of its ROC policy, such as trade. ${ }^{117}$ Moreover, some opposition members in the US, such as Representative Patrick Kennedy, continued to voice support for the referendum. ${ }^{118}$ The Congressional Taiwan Caucus also lobbied the President to change course and support the ROC referendum. ${ }^{119}$ On January 15, Ereli again made an announcement that the US opposed any moves that unilaterally changed the status quo in the strait, but at the same time praised Taiwanese democracy and pointed to the Bush administration's commitment to Taiwanese security. ${ }^{120}$

By not acting, the US sent a message that it was not going to enforce its will. With ample possible punishments available, especially trade sanctions and permanent cessation of weapon sales or military ties, the US administration refused to stand by its own statements and hold the ROC accountable for the referendum. It did not even threaten such actions; instead the US relied on the threat of non-interference should the PRC attack. While complete abandonment of the ROC was not possible, due to the TRA, more pressure could have been exerted on the ROC leadership at that point.

This strategy demonstrated the difficulties with trying to deter the ROC. While President Bush was against the referendum, the feeling was not universal within the US government, and Congress had, in the past, pushed forward legislation to strengthen US support of the ROC when Presidents seemed to move too far away. Moreover, the US still felt the need to have ROC support on trade and other issues. Complicating matters 
further was the apparent weakness of the US position, claiming not to oppose the referendum on principle but instead on what the president of the ROC might later do.

The US is deeply aware of its position at the pivot of an unwieldy situation. This is the difficulty of dual deterrence within a romantic triangle, since either wing could threaten to spurn the US if Washington did not aid as requested. Thus, the US made strong statements regarding its intentions and desires, and made no action to support them.

The PRC, possibly realizing the risk of mismanaging its PR and driving the US away, kept to the soft approach it had used. It worked hard to secure the support of other nations ${ }^{121}$ and restrained its comments, without mentioning possible attack. ${ }^{122}$ There were rumors of PLA training exercises designed to intimidate the ROC policy-makers, but even the ROC military command proclaimed that these were only rumors and that all PLA activities in the area were merely routine. ${ }^{123}$

On January $16^{\text {th }}, 2004$, Chen announced the exact nature of the referenda that the people of Taiwan would be considering. ${ }^{124}$ The resulting referendum consisted of two questions. Voters would be asked:

1) "The People of Taiwan demand that the Taiwan Strait issue be resolved through peaceful means. Should mainland China refuse to withdraw the missiles it has targeted at Taiwan and to openly renounce the use of force against us, would you agree that the government should acquire more advanced anti-missile weapons to strengthen Taiwan's self-defense capabilities?"

2) "Would you agree that our government should engage in negotiation with mainland China on the establishment of a "peace and stability" framework for cross-strait interactions in order to build consensus and for the welfare of the peoples on both sides?" 125 
In order for the results to be valid, at least one half of all of the voters would have to vote on the question. This lead many of those opposed to the referenda to ask their supporters to abstain from voting on the proposition, rather than voting against it. It was hoped that by combining those opposed to the referenda with those who failed to vote, the chances of defeating and invalidating the referenda would be much higher than having those opposed vote against the referenda.

The PRC sent out their first statement on the referenda topics the very next day, claiming that the Taiwanese people did not want the referenda, as the answers were "selfevident." "126 However, the "self-evident" answer was never explicitly stated by the PRC. Beyond this, however, the PRC reaction included no new rhetoric on the substance of the referenda, instead referring again to Chen's drive to destabilize cross-straits relations, using peace and democracy as a smokescreen. ${ }^{127}$ Indeed, in the next few days, Beijing officials gave many speeches, all of which stated that the referenda were the first step on the road to independence, without addressing the substance of the referenda. ${ }^{128}$

At the same time, the KMT within the ROC were trying hard to cancel the referenda, or else to obstruct it enough to defuse the crisis. ${ }^{129}$ The Executive Yuan, however, made it clear that any such action would be regarded as obstruction of government, and such officials would be punished. Chen saw no reason to give up on the referendum, as there was no evidence that he or the ROC would be punished by either the PRC or the US for holding it.

There was nothing new or noteworthy in the statements made by either the PRC or the ROC for the rest of the month, excluding the PRC gaining the support of Cambodia $^{130}$ and France ${ }^{131}$ in opposing the referendum. However, on January 30 , US Deputy Secretary of State Richard Armitage, in an interview on CNN from Beijing, gave 
the clearest summation on the US view of the referendum. He stated that, while the US was not opposed to referenda per se, it was concerned that these referenda were not legitimate. Armitage said that "[r]eferenda are generally reserved for very difficult and divisive issues, and the wording of the referendum, as I understand it, is neither difficult nor particularly divisive." ${ }^{\prime 32}$ He went on to say that the context was just as important as the wording, and that the US was keeping tabs on the situation, but at the same time that the US would not be locked into a course of action and would make its own decisions. ${ }^{133}$

This could be interpreted as a slight move back towards the ROC; however, if it was, it was so slight as to be unnoticed. Also, much like the PRC, while deriding the referendum questions as "neither difficult nor particularly divisive," he never said what the consensus on Taiwan was. He offered up no evidence to support his statements regarding the referenda. Instead, he explained that the US was still committed to strategic ambiguity.

At the same time, there was no action. His comments were mere boilerplate, a restatement of what was common knowledge. The administration's disapproval of the referendum was still toothless and conflicted. The statement was written off as mere rhetoric, since the US was unwilling to commit to any action. As every form of deterrence theory states, there can be no deterrent without a retaliatory threat to punish. It is the threat which reigns in the potential actor. The US, by not threatening some kind of penalty on the ROC for holding the referendum, had no ability to reign in the ROC. Deterrence also risks defection and strained relations, and the US would not risk that. Once again, the Bush administration attempted to influence the ROC through "cheap talk." 
Beijing apparently took this as a cue to again put pressure on the US to prevent the ROC from holding such a referendum. ${ }^{134}$ Many interpreted this as growing desperation on the PRC's part, because in the past the PRC had criticized the US for its involvement in "internal Chinese matters," such as the Taiwan issue. ${ }^{135}$ This came at the same time that members of President Bush's own party began criticizing him for his lack of support of the ROC. ${ }^{136}$

In response to criticism that he was engaging in separatism, Chen also called for the establishment of a framework for PRC-ROC dialogue, including a permanent exchange of officials. The primary principle of this framework would be peace. ${ }^{137}$ Zhang Mingqing, the spokesman for the PRC's State Council Taiwan Affairs Office, rejected this, saying that the "One-China" principle needed to be the bedrock of any such accord, not peace. Zhang went on to ask other nations to recognize Chen's "duplicity,",138 and dismissed a proposed "demilitarized zone" between the mainland and the island. 139

These proposals were an effort by the ROC to try to get US support by seeming to warm up to the PRC. As the US had long called on both the PRC and the ROC to engage in talks, it could be seen as a way to placate the US while not budging on the main dispute. However, since Chen had made no effort to meet the PRC's continued demand for full support of "one-China," it was obviously an attempt at reframing the issue, in a way that the PRC had done for quite some time. At the same time, it was obvious that it would not help bring about an end to the problems.

Zhang also engaged in a bit of reframing diplomacy. He reported that the PRC would not get involved in trying to influence the election, and did not care who won, as long as they were afterwards willing to abide by the One-China principle. ${ }^{140}$ This was an attempt by the PRC to bring attention back to the One-China principle, despite the fact 
that Chen would not accept the principle. Moreover, it was clear that his speech referred only to the presidential election, not the referenda. The referenda, on the other hand, could provoke a "strong response." 141 Moreover, the PRC military began asking the US military to intervene and stop the referendum. Undersecretary of Defense for Policy, Douglas Feith, confirmed that he had been asked to do so, without giving specifics on what it was the PRC wanted, but responded that it was best handled through diplomatic channels and there was nothing he could do. He did recommend, however, that the PRC redeploy some of its missiles in the name of reducing tension, which the PRC officials had no intention of doing. ${ }^{142}$

This was an amazing change from previous PRC stances. That PRC officials so valued the US relationship that they were willing to ask the US military to intervene is nothing short of amazing. However, again, the US demurred. While, to any American, it seems only proper that the State Department, rather than the Department of Defense, should be involved, it must be remembered that the State Department has only unofficial ties to the ROC, unlike Defense. Moreover, it was also a testament to the lack of success the State Department was having with the ROC that the PRC was willing to go to the US military to do it. While details were never given about what form of intervention the PRC wanted, the very idea of appealing to the US military to coerce the ROC government shows the seriousness of the issue from the PRC side.

The refusal to do so was seen as a possible tilt back towards the ROC after having stood, tentatively, with the PRC for the last few months on the referendum issue. ${ }^{143}$ The US may have started to feel that the PRC was overplaying its clout within Washington. Moreover, there is no guarantee that the US would have been able to force the ROC to change direction anyhow. Again, however, nothing more than words were exchanged. 
A stalemate ensued. The PRC, in particular, was worried about the possibility of inadvertently drumming up support for Chen and the referenda, as had happened in previous presidential elections. ${ }^{144}$ At the same time, Chen also sought to defuse some of the tension, by promising not to declare independence if reelected. ${ }^{145}$ However, the tension was increased again when Chinese President $\mathrm{Hu}$ Jintao set up office in the military compound of Yuquanshan, in order to better study plans for war with the ROC, if it was necessary. ${ }^{146}$ Chen, on the other hand, repeated a desire for peace, even saying that he hoped to one day shake Hu's hand at the signing of a peace agreement. ${ }^{147}$ However, in the run-up to the election, the ROC's own security preparedness was also increased, with military officials saying they were worried about possible PRC efforts to influence the elections or even attack the island. ${ }^{148}$

At the end of the month of February, Secretary of State Colin Powell again weighed in on the issue. His response, much like President Bush's, was that the US firmly opposed any efforts to change the status quo in the straits. He did not comment on whether the referendum would do that. ${ }^{149}$ This time, however, real action was taken at the same time. The USS Kitty Hawk made a five-day stop in Hong Kong, less than an hour's flight from the island of Taiwan. ${ }^{150}$ The US government and the commander of the vessel both proclaimed that the visit was merely coincidental, but some saw it as a warning to the PRC to avoid hostilities over the strait.

With this, further strategic ambiguity was spoken. The visit was friendly, showcasing the strong military ties between the US and the PRC. The visit by the Kitty Hawk was friendly, and in a PRC port, which shows the ROC that the US and the PRC are on good terms and that the ROC could not rely on the US breaking that. At the same time, however, it was clear that the Kitty Hawk would only be used against the PRC in 
the case of hostilities. The threat against the ROC has always been the withdrawal of military help, rather than military action against it, and the presence of the Kitty Hawk did not detract from the possibility of American action in the Taiwan Strait.

This was the first tangible act of deterrence to be seen in the whole episode. Despite the fact that prior to this almost every statement had been against the referendum, the US was only willing to show military action and purpose against the PRC. However, even this was an almost unnoticed and ambiguous signal, since it was a friendly visit with PRC permission. This stands in stark contrast to President Clinton's deployment of the carrier groups in 1996.

As the date for the referendum drew closer, the PRC and the ROC continued their appeals to the world. The PRC tried to get world leaders to call for the ROC to cancel the referendum, as Germany did on March $12 .{ }^{151}$ Reportedly, the PRC also tried to lobby the US Congress, which had been more sympathetic to the referendum than President Bush. ${ }^{152}$ The PRC Executive Vice Foreign Minister Dai Bingguo made visits to Germany, the US, and France to try to shore up support. ${ }^{153}$

At the same time, ROC officials tried to play down fears of trouble over the referendum. Mainland Affairs Council Chairwoman Tsai Ing-wen claimed that the PRC would be more flexible once the referendum was over. ${ }^{154}$ Soon after, Ing-wen also warned the PRC that pushing too strongly could make the Taiwanese people vote against Beijing's interests. ${ }^{155}$

In the days before the election, there were more reports of military activity. Rumors of the PRC moving heavy weaponry into the Fujian province surfaced, just across the strait from Taiwan. All leave in Fujian was cancelled, according to Taiwanese newspaper accounts, and the troops were told to be prepared to "achieve unification."156 
The PRC also had what it called routine naval exercises with France along the more northern parts of China's coast, ${ }^{157}$ which in the heightened tension led many to wonder about their intentions. However, the PRC also refrained from conducting war games near Taiwan, as it had in previous elections, ${ }^{158}$ and the ROC military seemed convinced that the naval exercises were not aimed at them. ${ }^{159}$ Breaking from the military, the ROC foreign ministry did claim that the PRC and France were both trying to influence the election with the exercise. ${ }^{160}$

These actions by the PRC show that, to a certain extent, they were not deterred by the USS Kitty Hawk. The assumed purpose of the Kitty Hawk was to tell the PRC not to interfere in Taiwan, yet the PRC was still preparing for such an eventuality. Even discounting the military exercises with France, given their extreme distance from the island, the mobilization in Fujian was frightening enough. The half measures taken by the US were obviously not enough to convince the PRC that the possible results of the election would be better than the punishments that the US might inflict.

At the same time, the ROC military took action on the worry that the PRC might attack. The ROC military was on high alert in the run-up to the election, even though the military said there was nothing unusual in the movements by the PRC. ${ }^{161}$ The ROC government was just as worried about domestic disturbances as they were attacks from the PRC. The National Police Administration issued a statement three days before the election promising to be neutral and to keep order during the voting. ${ }^{162}$

Then, the day before the election, President Chen Shui-bian and Vice President Annette Lu were shot. Chen took a bullet to the stomach while Lu's knee was grazed. Neither wound was life-threatening. The election still went on as planned, but the attacks were highly salient. ${ }^{163}$ Rumors immediately began circulating that it might have been a 
campaign trick, to drum up sympathy votes. ${ }^{164}$ Internal security was ratcheted up even further, with police ordered to find the gunman and to ensure security during the polling. ${ }^{165}$ The case was, however, handled as a purely domestic, non-political affair, with no accusations leveled by the government at the PRC or the opposition within Taiwan. ${ }^{166}$ The PRC had no comment, and did not broadcast the news about it within mainland China at the time. ${ }^{167}$

The election gave Chen the Presidency for another term, though the KMT and opposition both claimed that fraud and the failed assassination attempt were enough reason to annul the election results. ${ }^{168}$ With the victor receiving a mere $50.12 \%$ of the vote, many within the Pan-Blue Coalition called for a recount, which Chen at first resisted, and later accepted, as long as it went through the Judiciary. ${ }^{169}$ However, the opposition changed their demands, to asking the Judiciary to only recount disqualified ballots and ballots for Chen, rather than all ballots. ${ }^{170}$ An agreement was finally reached on April 12, and would include all ballots, including blank ballots not cast. ${ }^{171}$ Well after Chen had already been inaugurated, the high court came back and declared Chen Shuibian the President of the ROC. The court further declared that there was no reason to invalidate the election. ${ }^{172}$

The referenda did not receive enough votes to be valid, with only $45.17 \%$ voting on the missile referendum, and only $45.12 \%$ voting on the negotiations referendum, less than the $50 \%$ threshold. ${ }^{173}$ This was widely taken as proof that the Taiwanese people did not want to rock the boat; however, it must be noted that, of those that did cast ballots, the vote was $85 \%$ in favor. ${ }^{174}$ Provided that most of those who did not were protesting the referenda, it would suggest that, while the Taiwanese people were against them, it was 
not by an overwhelming majority. It is possible that the subjects were, in fact, difficult and divisive, contrary to the statements of US and PRC officials.

The PRC's reaction, while slow, was strong. PRC officials vowed not to interfere in the election dispute, but they again condemned the referenda. ${ }^{175}$ There were reports of PLA units being put on combat alert, in case the instability on the island worsened. ${ }^{176}$ However, they were ready to work with whoever won the presidential election, even Chen. ${ }^{177}$ As far as the PRC was concerned, for better or worse, the situation was back to where it was before Chen called for the referendum, except with explicit proof that the Taiwanese people were not willing to provoke the PRC.

As for the United States, it had nothing to add after the election. President Bush congratulated Chen, pending the "legal difficulties." 178 After the election was over, the ROC agreed to buy from the US an advanced military radar system. This was seen as an effort by Chen to reach back out to Bush, after losing the US President's support on the referendum issue. ${ }^{179}$ Left unsaid was that the US was still willing to sell them to the ROC, despite the crisis Chen had invited, and his unwillingness to back down or accept US criticism. Relations between the ROC and the US went back to where they had been before, and the romantic triangle remained.

In the end, the ROC was able to go through with exactly what it wanted, even if the results were not what the ROC leadership sought. The efforts by the US to convince the ROC not to hold the referendum were weak, and ultimately fruitless. The ROC was not deterred one bit. The relationships between the US and both the PRC and the ROC were maintained, which seemed to be the overwhelming priority of the administration, but neither the PRC nor the ROC government was deterred. It is possible that the administration's message was heard more clearly by the Taiwanese people, who refused 
to provoke the PRC by passing the referenda, and the opposition parties within the ROC. However, it did not affect much, because the Pan-Green Alliance maintained its position within the government. 


\section{CHAPTER V}

\section{CONCLUSIONS}

While few scholars have focused on this issue, the referendum crisis of 2003 and 2004 shows how American policy toward the Taiwan issue has changed. Instead of focusing on deterring both the PRC and the ROC, the US government has decided to avoid actions that would damage its relationships with both the PRC and the ROC. This helped in the post-crisis environment, as everything quickly settled, but it does lead to questions about future responses.

Before the crisis began, many considered the Bush administration to be clearly, completely pro-ROC. Therefore, many were surprised at its initial reaction to the proposed referendum. By standing with Premier Wen Jiabao and announcing opposition to the (not yet finalized) referendum, many saw the US as taking a strong turn towards Beijing. A clearer message would have been difficult. (While the wording was ostensibly aimed at both sides of the Taiwan Strait, by standing next to the PRC Premier and agreeing with him, it was a completely pro-PRC statement.)

However, Chen and the ROC administration did not back down or waver from their determination to have a referendum, and the US did nothing to push the ROC beyond cheap talk. At most, the ROC may have watered down the wording in order to make it more palatable to the United States. This cannot be certain, as there were no leaks of early versions, but it was widely conjectured. In response, the US withdrew its 
opposition, but refused to extend its approval. In the end, this proved to the ROC to be a distinction without a difference. At the same time that the US continued to question the referendum, with even then-Secretary of State Colin Powell expressing mild disapproval, ${ }^{180}$ the ROC held firm, and made no more changes.

Admittedly, the referenda did not stake out extreme positions, though they were characterized as such. It must be remembered that at no time during the crisis did Chen suggest declaring independence through referendum. At worst, he had suggested possible revision of the constitution via referendum, possibly a few years down the road.

At the same time, the US did not approve of PRC pressure on the ROC; however, the attempts to show this disapproval of military pressure did not help either. The US sent a carrier to Hong Kong, possibly to remind the PRC that the US was still the predominant naval power in the world. The PRC was not deterred by the US. The fact that the PRC did not try missile tests or military action in the waters near Taiwan to influence the election is telling. This could be attributed to the success of previous American deterrence, but the PRC was still engaged in coercive behavior. It is obvious that previous attempts at coercion had backfired, such as the 1996 crisis, and so the PRC instead attempted to convince the US to stop the referendum, while engaging in military preparation on the mainland. This preparation, coupled with vague threats sent towards the ROC, was still coercive. While no invasion of the island commenced, the US wanted (in theory) to prevent the PRC from attempting to coerce the ROC. This failed.

It also should be noted that PRC deterrence too failed. The threats of war were never acted upon. While a senior PRC military official accused the ROC of pushing the straits to the "abyss of war," nothing was done to punish the ROC. A strong argument can be made that, since the PRC made threats regarding the referendum, and did not act 
on them even as the referendum was held, the PRC's future credibility may be damaged, emboldening future ROC attempts. It should be remembered that many of the threats were not dependent on the referenda passing, but instead on the ROC holding them. Of course, no one in the ROC could have believed the PRC threats. The threats were not commiserate with the threat posed by the referendum. The PRC has long made clear that a declaration of independence would be followed by an attack; this referendum did not even address independence. Therefore, talk of invasion was probably dismissed by man in the ROC government, until near the end when the PRC geared up its military. These military threats from the PRC seem more likely to have been posturing, seeking support for future anti-secessionist endeavors.

While making these military threats, the PRC was unwilling to take measures commiserate with the crisis. The PRC could have threatened to cut trade relations with the ROC or to end extradition, but instead relied on a strategy of getting as many foreign governments as possible to denounce the referenda. This seems to reveal a fundamental contradiction in the PRC's policy towards the ROC. The PRC demands that no other state meddle in the internal affairs of China, including Taiwan. At the same time, the PRC wants other states need to pressure the ROC (part of China) into not having a referendum. In the end, many in Chen's administration must have been glad to see the PRC beg other states to come out against the referendum, because it meant a tacit acknowledgement that the ROC was practically independent, and the PRC could not stop them.

This all may have had the reverse effect of telling the secessionist forces on the ROC that the PRC has no ability to impose consequences on the island. It would be foolhardy for anyone within the ROC to take such a lesson from this crisis and thus push 
for de jure independence, but the lack of punishment for Taipei could cause it to consider further provocations, particularly if a more pro-independence candidate, such as Annette $\mathrm{Lu}$, were to become president.

The only party to come out clearly ahead in the referendum crisis was the one that arguably started it: the ROC. While the referenda failed, they were held, despite the wishes of both the PRC and the US. After the referenda, the US relationship to the ROC seemed to go back to exactly its previous state, with large weapons sales in the waiting. Since then, the PRC has even begun working more closely with the ROC, ${ }^{181}$ despite the fact that Chen is still the President and has recently called for yet more provocative steps that will anger the PRC. ${ }^{182}$ The ROC lost nothing; both the PRC and the US lost credibility in the Strait.

Both sides of the Taiwan Strait have strong ideological and identity-related reasons for the actions they take. This creates a strong disincentive to compromise. Despite what many scholars think, attempting to bridge those divides, particularly while Taiwanese nationalists are in power in the ROC, will be impossible.

This all shows that, while every side had a stake in the outcome, none of the states (excepting possibly the ROC) was committed enough to the outcome to risk its relationships. The only actors that may have been deterred were the PRC and the citizens of the ROC. The PRC did not attack, and the ROC citizens voted against the referenda. However, deterrence is notoriously hard to prove, and the few actions that the US took do not seem the type designed to create deterrence. Moreover, the referenda were not that popular in the ROC, and it is impossible to tell how many voters would have voted in favor if not for PRC threats. Its also impossible to know how many of the null votes were actually votes against the referenda and how many reflected apathy. 
After years of policy pronouncements and ambiguity, all sides have developed their own ideas of how the US will react to a given provocation. Therefore, when the only threat and punishment given out by the US is in regard to future behavior during a hypothetical invasion, it should not be considered during lesser crises. Tensions between the two sides of the Strait can continue to flare up to the level of violence, without the US being a factor. Higher tension levels also raise the chances of inadvertent attack, and so it would seem to be in the best interest of the US to try to keep tension low. This is seen in the willingness of the US to become involved in the dispute, but the methods did nothing to contribute to a lowering of tensions. The US consistently put out its message, but did nothing to support it.

In this case, this tactic worked. Neither relationship was jeopardized. Both of the relationships, the PRC-US and the ROC-US, are so important to American planning that US policy makers are very constrained. The US felt that it needed the PRC too much on other issues, notably North Korea and the war on terror, to risk anything that angered the PRC leadership. At the same time, the general US sympathy towards the ROC, as a liberal democracy with long-standing ties to the US, prevents any administration from pressuring it too strongly. Moreover, the US still hopes for the ROC to buy advanced weapons from the US, which have been very controversial within the ROC. True ambiguity would require American officials to at least risk all of these things, something that the current administration is not willing to do.

Since the US seems unwilling or unable to truly engage in ambiguity and dual deterrence, some may argue that the US should instead engage in total clarity. Of course, this does not actually follow. As it is, the written agreements between the US and the PRC, along with the TRA, make any form of clarity impossible. Beyond that, if the US 
had unreservedly sided with the ROC, then the ROC would still have provoked the PRC. In addition to that, it may have simply made the PRC feel more cornered, and it might have instead resorted to more drastic measures. There is also the possibility that the referenda would have been successful, which would have also provoked the PRC. On the other hand, the US already sided with the PRC, though not unreservedly, and it did not change the ROC leadership's behavior. Perhaps full clarity, in the form of announcing that the US would not support the ROC against a PRC attack, would have induced the ROC leadership to drop the referendum, but that would have required sacrificing the relationship with the ROC. There would not have been the necessary domestic support for such a policy. In either case, the US would have lost good relations with one partner without assurances that it would have prevented war.

With no ability to tack back and forth in ambiguity, and with clarity discounted, the US is left with only one option. The US is left with a policy of pleasing everyone and offending no one. This leaves the US unable to affect the recurring crises in the Taiwan Strait before they become violent. Dealing with the tension in the Taiwan Strait involves serious risk taking and possible loss of support from one or both parties. The US very effectively communicated its preferences, but by not taking action to support them, no one listened. Previous administrations were willing to take action, or at least make threats, against both the PRC and the ROC in order to get results. Whether it was with aircraft carrier groups or trade agreements, prior administrations were willing to stand up and take stands, while still tacking back-and-forth under a cloud of ambiguity. Even in situations where the stakes were as low as this, as with Lee Teng-hui's visit, previous administrations had worked to keep both sides happy and tension low. 
Actual measures would have to be taken and actual threats issued for the US to effectively deter either side, let alone both. This would have risked upsetting either of the relationships that the US has spent so much effort cultivating. As strategic triangles logic reveals, the US wants to keep strong relations with both. To do so, it must keep both placated. Deterrence and good relations can thus be seen as contradictory; this administration has picked good relations over deterrence.

Instead of trying to come up with new rhetoric or new ways of communicating its interests, the US must come to accept that, without taking risks and revealing a willingness to play the role of a pivot, it will not be able to influence events in recurring crises. Even then, it is possible that crises are unavoidable anyway. This is a hard lesson for any power, particularly a superpower like the US, to learn. However, it seems that the US has accepted that, past certain limits, the ROC and the PRC are both undeterrable. Therefore, instead of trying to deter both sides during every single crisis, the US has instead committed itself to keeping relations strong with both.

With all of this in mind, it is difficult to make a policy pronouncement. Instead, it is enough, for now, to simply note that the approach the US takes to the problem has shifted significantly. Moreover, strategic triangle theory cannot make policy pronouncements, but instead focuses on the dynamics of the relationship. With this in mind, as long as the PRC and the ROC can avoid erupting into violent conflict, it seems that the romantic triangle in the Strait will continue indefinitely. 


\section{ENDNOTES}

${ }^{1}$ Boese, Wade, "Taiwan Proposes Controversial Vote on Chinese Missiles," Arms Control Today 34:1 (Jan/Feb 2004, Washington) p. 33

${ }^{2}$ Ibid.

${ }^{3}$ It is included in Wu, Yu-Shan, "From Romantic Triangle to Marriage? WashingtonBeijing-Taipei Relations in Historical Comparisons" Issues \& Studies 41:1 (March 2005), but only as an exception to an overall trend.

${ }^{4}$ Schelling, Thomas, The Strategy of Conflict (Oxford University Press: New York, 1977)

${ }^{5}$ Ibid., p. 127

${ }^{6}$ Ibid., p. 187

${ }^{7}$ Ibid., p. 188

${ }^{8}$ Ibid.

${ }^{9}$ Ibid., p. 194

${ }^{10}$ Chan, Steve, "Extended Deterrence in the Taiwan Strait: Learning from Rationalist Explanations in International Relations," World Affairs, Fall 2003 p. 166-191

${ }^{11}$ Ibid.

${ }^{12}$ Chan, Steve, "Prognosticating About the Taiwan Strait," World Affairs, 168:1 (Summer, 2005) p. 22

${ }^{13}$ Zagare, Frank C. and Kilgour, D. Marc, "Alignment Patterns, Crisis Bargaining, and Extended Deterrence: A Game-Theoretic Analysis," International Studies Quarterly 2003 No. 47

${ }^{14}$ Ibid p. 592

${ }^{15}$ O'Hanlon, Michael, "Why China Cannot Conquer Taiwan," International Security 25:2 (Autumn 2000) p. 51-86

${ }^{16}$ This is most common in works on policy, rather than theory. See Benson, Brett V. and Niou, Emerson M. S., "Comprehending Strategic Ambiguity: US Policy Toward Taiwan Security," Taiwan Security Research, April 2000, http:/taiwansecurity.org/IS/IS-Niou0400.htm ; also, Pan Zhongqi, "US Taiwan Policy of Strategic Ambiguity: a Dilemma of Deterrence" Journal of Contemporary China 12:35 p. 387-407

${ }^{17}$ Pinsker, Roy, "Drawing a Line in the Taiwan Strait: 'Strategic Ambiguity and Its Discontents," Australian Journal of International Events 57:2 (July 2003) p. 353-368

${ }^{18}$ Pan Zhongqi, "US Taiwan Policy of Strategic Ambiguity: a Dilemma of Deterrence" Journal of Contemporary China 12:35 p. 393-394

${ }^{19}$ For example, see Niou and Benson or Pan Zhongqi.

${ }^{20}$ Schelling, p. 13

${ }^{21}$ Dittmer, Lowell, "The Strategic Triangle: An Elementary Game-Theoretical Analysis", World Politics, 33:4 (July 1981) p. 490-1 
${ }^{22}$ All of these, except for the "unit veto," are found in Dittmer. For the "unit veto," see Yu-shan Wu.

${ }^{23} \mathrm{Wu}$, Yu-Shan, "From Romantic Triangle to Marriage? Washington-Beijing-Taipei Relations in Historical Comparisons" Issues \& Studies 41:1 (March 2005) p. 118

${ }^{24}$ Dittmer., p. 510

${ }^{25} \mathrm{Wu}, \mathrm{Yu}$-Shan, "From Romantic Triangle to Marriage? Washington-Beijing-Taipei

Relations in Historical Comparisons" Issues \& Studies 41:1 (March 2005) p. 121

${ }^{26}$ Ibid., p. 147

${ }^{27}$ Ibid., p. 139

${ }^{28}$ Ibid.

${ }^{29}$ Knapp, Ronald G., "The Shaping of Taiwan's Landscape," Taiwan: A New History, Murray A. Rubinstein, ed., (M.E. Sharpe, Armonk, NY) 1999 p. 9

${ }^{30}$ Will, John E., "The Seventeenth Century Transformation: Taiwan Under the Dutch and the Cheng Regime," Taiwan: A New History, Murray A. Rubinstein, ed., (M.E. Sharpe, Armonk, NY) 1999 p. 85

${ }_{31}^{31}$ Ibid., p. 93-95

${ }^{32}$ Ibid., p. 101-102

${ }^{33}$ Shepherd, John R., "The Island Frontier of the Ch'ing," Taiwan: A New History,

Murray A. Rubinstein, ed., (M.E. Sharpe, Armonk, NY) 1999 p. 112-113

${ }^{34}$ Ibid., p. 115-120

${ }^{35}$ Gardella, Robert, "From Treaty Ports to Provincial Status, 1860-1894," Taiwan: A New History, Murray A. Rubinstein, ed., (M.E. Sharpe, Armonk, NY) 1999 p. 163

${ }^{36}$ Lamley, Harry J., "Taiwan Under Japanese Rule, 1895-1945: The Vicissitudes of Colonialism," Taiwan: A New History, Murray A. Rubinstein, ed., (M.E. Sharpe, Armonk, NY) 1999 p. 201-209

${ }^{37}$ Phillips, Steven, "Between Assimilation and Independence: Taiwanese Political Aspirations Under Nationalist Chinese Rule, 1945-1948," Taiwan: A New History, Murray A. Rubinstein, ed., (M.E. Sharpe, Armonk, NY) 1999 p. 277

${ }^{38}$ Ibid., p. 280

${ }^{39}$ Ibid., p. 282

${ }^{40}$ Wang, Peter Chen-main, "A Bastion Created, A Regime Reformed, An Economy Reengineered, 1949-1970," Taiwan: A New History, Murray A. Rubinstein, ed., (M.E. Sharpe, Armonk, NY) 1999 p. 321

${ }^{41}$ Ibid., p. 321-324

${ }^{42}$ Ibid., p. 321

${ }^{43}$ Bush, Richard C., Untying the Knot: Making Peace in the Taiwan Strait, (Broking Institution Press: Washington, D.C, 2005) p. 18

${ }^{44}$ Bush., p. 19

${ }^{45}$ Ibid. p. $19-20$

${ }^{46}$ Ibid.

${ }^{47}$ Ibid., p. 21

${ }^{48}$ Ibid., p. 22

${ }^{49} \mathrm{Wu}, \mathrm{Yu}$-Shan, p. 120

${ }^{50}$ Ibid., p. 22-25

${ }^{51}$ Ibid., p. 25

${ }^{52}$ Ibid., p. 24 
${ }^{53}$ Ibid., p. 23-24

${ }^{54}$ Garrison, Jean A., Making China Policy: From Nixon to G.W. Bush (Lynne Reinner Publisher: Boulder, New York, 2005) p. 133

${ }^{55}$ Dietrich, John W., "Interest Groups and Foreign Policy: Clinton and the China MFN Debates," Presidential Studies Quarterly 29:2 (1999) p. 287-8

${ }^{56}$ Ibid., p. 293

${ }^{57}$ Garrison., p. 144

58 Ibid., p. 144

59 Ibid.

${ }^{60}$ Ibid., p. 145

${ }^{61}$ Ibid., p. 151

${ }^{62}$ Ibid., p. 171

63 Ibid.

${ }^{64}$ Ibid., p. 175

${ }^{65}$ Quan Jing, "Militarization of the Taiwan Strait Issue," Reflections on the Triangular Relations of Beijing-Taipei, Washington since 1995, ed. Shiping Hua, (Palgrave MacMillan: New York, 2006) p. 95

${ }^{66}$ Bush, Richard C., At Cross Purposes: US - Taiwan Relations Since 1942 (M.E. Sharpe: Armonk, New York, 2004) p. 124

${ }^{67}$ Zagoria, Donald S., Breaking the China-Taiwan Impasse, (Praeger: Westport, 2003) p. 223

${ }^{68}$ Ibid.

${ }^{69}$ Ibid., p. 224-226

${ }^{70}$ Bush, Richard C., At Cross Purposes: US - Taiwan Relations Since 1942 (M.E.

Sharpe: Armonk, New York, 2004) p. 138-142

${ }^{71}$ Zagoria, Donald S., Breaking the China-Taiwan Impasse, (Praeger: Westport, 2003) p. 227-228

72 Ibid., p. 228

${ }^{73}$ Ibid. p. 230

${ }^{74}$ Bush, Richard C., At Cross Purposes: US - Taiwan Relations Since 1942 (M.E. Sharpe: Armonk, New York, 2004) p. 155

${ }^{75}$ Ibid.

${ }^{76}$ Zagoria, Donald S., Breaking the China-Taiwan Impasse, (Praeger: Westport, 2003) p. 238

${ }^{77}$ Ibid.

${ }^{78}$ Bradsher, Keith, "Taiwan's Leader Campaigns, With a Stop in the US," The New York Times, October $30^{\text {th }}, 2003$, p. A6

79 -- "Constitutional Reform to Deepen Taiwan's Democracy," China Post, November $16^{\text {th }}, 2003$

80 -- "Chen's Plan A Blueprint for Disaster," Xinhua November 11, 2003

81 -- "Chinese FM spokesman on US Official Taiwan-related Remarks," Xinhua,

November 11, 2003

82 -- "Mainland Warns Chen Shui-bian of Bottom Line," Xinhua, November 24, 2003

83 -- "Chen Shui-bian's 'Independence Referendum' Plot Foiled," Xinhua, December 2, 2003

84 Ibid. 
85 Ibid.

${ }^{86}$ Bradsher, Keith, "Beijing Softens Stance Against Taiwanese Law," The New York Times November $28^{\text {th }}, 2003$, p. A7

${ }^{87}$ Shanker, Thom, "U.S. Says China is Stepping Up Short-Range Missile Production," The New York Times, July $31^{\text {st }}, 2003$ p. A5

${ }^{88}$ Ibid.

${ }^{89}$ Taipei Representative Office in Hungary, "Referendum Aimed at China's Missiles," Taiwan Monthly, December, 2003, p. 1

${ }^{90}$--, "Taiwan Will Not Hold Referendum on Sovereignty Change-Spokesman," $B B C$ Monitoring International Reports, December 2, 2003

91 --, "PLA: Chen to Blame if War Breaks Out," Xinhua, December $3^{\text {rd }}, 2003$

92 Bradsher, Keith, and Joseph Kahn, "Running for Reelection, Taiwan Leader Takes on China," The New York Times, December 5, 2003 p. A7

93 Ibid.

94 Ibid.

95 Ibid.

${ }^{96}$ Sanger, David, "US Asks Taiwan to Avoid a Vote Provoking China," The New York Times, December $9^{\text {th }}, 2003$, p. A1

${ }^{97}$ Sanger, David, "Bush Lauds China as 'Partner' in Diplomacy," The New York Times, December 10, 2003, p. A6

98 --, "US Two-Faced Stance on Taiwan Damaging: Newspaper," Xinhua, December $5^{\text {th }}$, 2003

99 --, "Bush Slam's Taiwan's Stand," The Weekend Australian, December $13^{\text {th }}, 2003$ p.T06

${ }_{100}$ Pelosi, Nancy, "President Bush Must Not Abandon US Commitment to Democracy, Including in Taiwan," Capitol Hill Press Releases December 10 $0^{\text {th }}, 2003$

101 --, "Bush Slam's Taiwan's Stand," The Weekend Australian, December $13^{\text {th }}, 2003$

p.T06

102 --, "Taiwan Parties React to Chinese Premier's Meeting with Bush," BBC Worldwide Monitoring, December 11, 2003

103 Ibid.

104 --, "Taiwan Security Official Visits US to Explain Referendum Issue - Agency," $B B C$ Monitoring International Reports December 13, 2003

105 -.-, "Taiwan President Poses Three Questions to Mainland Counterpart," BBC

Monitoring International Reports, December $13^{\text {th }}, 2003$

106 --, "Taiwan President Says Ruling Party's View Coincides With That of USA," $B B C$ Monitoring International Reports, December $16^{\text {th }}, 2003$

107 --, "Chinese Premier's Four-Nation Tour Fruitful: FM," Xinhua, December 16, 2003

108 --, "Military Cooperation Contributes to Better Sino-Russian Ties, Say Ministers," Xinhua, December $16^{\text {th }}, 2003$

109 --, "Chinese Official Says Taiwan Referendum a 'Serious Provocation," Xinhua

December 17, 2003

${ }^{110}$ Huang Kwang-chun, "Taiwan Official Says, 'Defensive Referendum' Not

Provocative," BBC Worldwide Monitoring December $18^{\text {th }}, 2003$

${ }^{11} \mathrm{Wu}$, Sofia, "Taiwan Military to Respond to China's Action in Line with Combat Regulations," BBC Worldwide Monitoring December $18^{\text {th }}, 2003$ 
112 --, "Taiwan President to Revoke "Five Noes" Promise if Threatened by Missiles," Taipei Times, December $23^{\mathrm{rd}}, 2003$

113 --, "Taiwan Vice President Comments on EU Arms Sale Ban, Other Issues," BBC Monitoring International Reports, December 26 $6^{\text {th }}, 2003$; Chang, Maubo, "Taiwanese Vice-President Comments on China Missile Issue," BBC Worldwide Monitoring, December $31^{\text {st }}, 2003$

114 --, "Taiwan Official: Beijing's 'Soft' Approach Cannot Disguise Deployed Missiles," $B B C$ Monitoring International Reports, December $26^{\text {th }}, 2003$

115 --, "Chen Shui-bian Denounced as "Immoral" for Anti-Mainland Statement," Xinhua, December $31^{\text {st }}, 2003$

116 --, "Taiwan President Vows to Go Ahead with Referendum," BBC Monitoring International Reports, January 1, 2004

${ }^{117}$ Wu, Sofia, "Taiwan, US to Resume TIFA Talks: BOFT," Central News AgencyTaiwan, January $6^{\text {th }}, 2004$

118 --, "Taiwan President Emphasizes Desire for Peace to Visiting US Congressman," BBC Monitoring International Reports, January 7, 2004

119 --, "Rep. Wexler Travels to Taiwan For International Parliamentary Forum on AsiaPacific Security," State News Service, January 8, 2004

${ }^{120}$ This was in a speech at the Foreign Press Center Briefing on January $14^{\text {th }}, 2004$; see http://pc.state.gov/fpc/28196.htm

121 --, "Indonesia Opposes Taiwan Independence: FM," Xinhua, January $6^{\text {th }}, 2003$; --, "Proposed Taiwan 'Referendum' Risky: Lao Deputy PM," Xinhua

122 --, "Referendum Threatens Peace Across Taiwan Strait: Official," Xinhua, January $14^{\text {th }}, 2004$

${ }^{123}$ Wu, Sofia, "Taiwan-US Military Exchanges "Proceed Steadily" - Defence Minister," $B B C$ Monitoring International Reports, January $15^{\text {th }}, 2004$

124 --, "Taiwan President Announces Referendum Contents," BBC Monitoring International Reports, January $16^{\text {th }}, 2004$

125 --, "Taiwan Election Commission Issues Referendum Results," BBC Worldwide Monitoring, March 20, 2004

126 --, "Chinese Mainland Condemns Taiwan's 'Referendum' As Provocative," Xinhua, January $17^{\text {th }}, 2004$

127 Ibid.

${ }^{128}$ For instance, see --, "Chinese Official Criticizes Taiwan Leader's Announcement of Referendum Topics," Xinhua, January 17 $7^{\text {th }}, 2004$; --, "China's Taiwan Affairs Spokesman Condemns Taipei's Proposed Referendum," Xinhua, January $17^{\text {th }}, 2004$ ${ }^{129}$ Kuo, Deborah, "A spokesman for Taiwan's Executive Yuan has said that local governments and public functionaries who boycott the proposed 20 March referendum may face disciplinary proceedings. He also said that if faced with obstructions, the government may have to implement the referendum forcefully." Central News AgencyTaipei, January $18^{\text {th }}, 2004$

130 --, "Cambodian Government 'Condemns' Taiwan Referendum Proposal," Agence Kampuchea Presse, January $28^{\text {th }}, 2004$

131 --, "France Reiterates One-China Stand," Xinhua, January 27, 2004 
132 This interview can be found on the State Department's website, http:/www.state.gov/s/d/former/armitage/remarks/28615.htm. The interview was conducted on January 30, 2004.

133 Ibid.

${ }^{134}$ Kah, Joseph, "Beijing Urges Bush to Act to Forestall Taiwan Vote," The New York Times, February 6, 2004, p. A3

135 Ibid.

${ }^{136}$ Li Wen-chi and Chang, Maubo, "Several US Congressmen Support Taiwan

Referendum," Taiwanese Central News Agency, February 6, 2004

${ }^{137}$ Kuo, Deborah, "Taiwan President Calls for Cross-Strait 'Peaceful Interaction' Accord," Taiwanese Central News Agency, February 3, 2004

${ }^{138}$ Chen Binhua and Zhang Yong, "China's Taiwan Affairs Office spokesman criticizes Chen's 'duplicity', Xinhua, Feburary 11, 2004

${ }^{139}$ Cody, Edward, and Pan, Philip, "China Rejects Taiwan's Proposal for DMZ; Island's Government Told Planned Referendum Would 'Endanger Peace", The Washington Post, February 12, 2004, p.A26

140 -., "China Pledges Not to Get Involved in Taiwan Elections," Agence France Presse February 11, 2004

${ }^{141}$ Cody, Edward, and Pan, Philip, “China Rejects Taiwan's Proposal for DMZ; Island's Government Told Planned Referendum Would 'Endanger Peace", The Washington Post, February 12, 2004, p.A26

142 Ibid.

${ }^{143}$ Kahn, Joseph, "US Asks China to Trim Threat to Taiwan," The New York Times, February 11, 2006, p. A12

${ }^{144}$ Wu, Lilian, "Beijing More Restrained, But Continues Tirade Against President: SEF," Taiwanese Central News Agency February 19, 2004

${ }^{145}$ Low, Stephanie, "No Plan for Taiwan Independence, Promises President Chen," Agence France Presse, February 19, 2004

${ }^{146}$ Cheong, Ching, "Chinese president takes part in war plans; Hu sets up office at military command headquarters to familiarise himself with operations, as Taiwan referendum nears," The Straits Times, February 21, 2004

${ }^{147}$ Wu, Sofia, "President Reaffirms Commitment to Making Peace with Beijing," Taiwanese Central News Agency, February $21^{\text {st }}, 2004$

${ }^{148}$ Wu, Sofia, "Military, Security Units Heighten Alert Ahead of Election," Taiwanese Central News Agency, February 23, 2004

149 --, "Powell Stresses US Opposition to Taiwan Changing Status Quo: China," Agence France Presse, February 24, 2004

150 .-, "Carrier's Presence No Coincidence," China Post, March 8, 2004

151 --, "Germany Asks Taiwan to Cancel Referendum," Xinhua, March 12, 2004

152 --, "PRC Tries to Influence US Congress' Stance on Taiwan," China Post, March 14, 2004

153 --, "China Steps Up Diplomatic Pressure on Taiwan," Press Trust of India, March 14, 2004

${ }^{154}$ Wu, Sofia, "Wen's Words Reflect Inflexibility in Handling Cross-Straits Ties: MAC," Taiwanese Central News Agency, March 14, 2004

155 --, "Chinese Criticism Could Backlash, Tsai Says," China Post, March 15, 2004 
156 --, "Unusual Movements in Fujian, HK Daily Reports," China Post, March 15, 2004

${ }^{157}$ Graham, Robert, and McGregor, Richard, "France joins China in naval exercises as

Taiwan prepares to go to the polls," The Financial Times, March 16, 2004 p. 10

${ }^{158}$ Gertz, Bill, "Beijing quiet ahead of election; War games absent as Taiwan prepares for voting," The Washington Times, p.A3

${ }^{159} \mathrm{Wu}$, Sofia, "Taiwan Plays Down China-France Naval Exercise," Taiwanese Central News Agency, March 16, 2004

160 --, "Taiwan Says China Trying to Influence Election By Staging Military Exercise With France," Taipei Times, March 17, 2004

${ }^{161} \mathrm{Wu}$, Sofia, "Taiwan Military on Heightened Alert Ahead of Presidential Poll," Taiwanese Central News Agency, March 16, 2004

${ }^{162}$ Huang, Luis, "NPA Chief Outlines Four Principles to Uphold Order During Election," Taiwanese Central News Agency, March 17, 2004

163 --, "Taiwan's President Shot; Election Not Cancelled," Japan Economic Newswire, March 19, 2004

164 --, "ROUNDUP:Taiwan's president, vice president shot while campaigning,"

Deutsche Presse-Agentur, March 19, 2004

${ }^{165}$ Chang, Maubo, "Premier Orders Law-Enforcement To Find Shooter As Soon As

Possible," Taiwanese Central News Agency, March 19, 2004

${ }^{166}$ Ibid.

${ }^{167}$ McDonald, Joe, "China Silent After Shooting of Taiwanese Leaders," The Associated Press, March 19, 2004

${ }^{168}$ Foreman, William, "Ruling Party Claims Taiwan's President Wins Presidential Election After Assassination Attempt," Associated Press, March 20, 2004

${ }^{169}$ Bradsher, Keith, and Kohn, Joseph, "Taiwan President Agrees to Recount of Disputed Vote," The New York Times, March 23, 2004, p. A9

${ }^{170}$ Chang, Maubo, "Court Opens Hearing in Lawsuit to Nullify Presidential Elections," Taiwanese Central News Agency April 2, 2004

171 --, "Attorneys in Taiwan Presidential Election Case Agree on Terms for Re-count," Taiwanese Central News Agency, April 13 ${ }^{\text {th }}, 2004$

${ }^{172}$ Chang, Maubo, "Opposition Loses Case Against President," Taiwanese Central News Agency, November 4, 2004

173 --, "Taiwan Election Commission Issues Referendum Results," BBC Worldwide Monitoring, March 20, 2004

${ }_{174}^{175}$ Ibid.

175 --, "China Condemns Failed Taiwan Referendum," Agence France Presse, March 20, 2004

176 --, "China's Military on Combat Alert Over Taiwan's Crisis: Paper," South China Morning Post, March 21, 2004

177 -., "China Condemns Failed Taiwan Referendum," Agence France Presse, March 20, 2004

178 Valencia, Mark J., "Taiwan's Young Democracy Shaken; Disputed Vote Heats Up Debate Over 'One China' Vs. Island 'Identity'," Washington Times, p. A15

${ }^{179}$ Hille, Kathrin, "Taiwan to Buy US Radar System, Controversial Defence Purchase," Financial Times, April 2, 2004 p. 2 
180 --, "Powell Stresses US Opposition to Taiwan Changing Status Quo: China," Agence France Presse, February 24, 2004

${ }^{181}$ For example, deportations from the PRC to the ROC have become more common. See --, "China deports 25 suspects to Taiwan," Al-Jazeera International January 27, 2007 ${ }^{182}$ The clearest example of this is Chen's call to change the ROC postal service from the "China Post" to the "Taiwan Post" and removing the name "Republic of China" from its postal stamps, instead putting "Taiwan" on them. See Grauwels, Stephanie, "Taiwanese President playing name game," AP February 8, 2007 


\section{REFERENCES}

Benson, Brett V. and Niou, Emerson M. S., "Comprehending Strategic Ambiguity:

US Policy Toward Taiwan Security," Taiwan Security Research, April 2000, http://aiwansecurity.org/IS/IS-Niou-0400.htm

Boese, Wade, "Taiwan Proposes Controversial Vote on Chinese Missiles," Arms Control Today 34:1 (Jan/Feb 2004, Washington)

Bush, Richard C., At Cross Purposes: US - Taiwan Relations Since 1942 (M.E. Sharpe: $\quad$ Armonk, New York, 2004)

Bush, Richard C., Untying the Knot: Making Peace in the Taiwan Strait, (Broking Institution Press: Washington, D.C, 2005)

Chan, Steve, "Extended Deterrence in the Taiwan Strait: Learning from Rationalist Explanations in International Relations," World Affairs, Fall 2003

Chan, Steve, "Prognosticating About the Taiwan Strait," World Affairs, 168:1 (Summer, 2005)

Dittmer, Lowell, "The Strategic Triangle: An Elementary Game-Theoretical Analysis", World Politics, 33:4 (July 1981)

Gardella, Robert, "From Treaty Ports to Provincial Status, 1860-1894," Taiwan: A New History, Murray A. Rubinstein, ed., (M.E. Sharpe, Armonk, NY) 1999

Garrison, Jean A., Making China Policy: From Nixon to G.W. Bush (Lynne Reinner Publisher: Boulder, New York, 2005)

Knapp, Ronald G., "The Shaping of Taiwan's Landscape," Taiwan: A New History, Murray A. Rubinstein, ed., (M.E. Sharpe, Armonk, NY) 1999

Lamley, Harry J., "Taiwan Under Japanese Rule, 1895-1945: The Vicissitudes of Colonialism," Taiwan: A New History, Murray A. Rubinstein, ed., (M.E.

Sharpe, $\quad$ Armonk, NY) 1999

O'Hanlon, Michael, "Why China Cannot Conquer Taiwan," International Security 25:2 (Autumn 2000) 
Pan Zhongqi, "US Taiwan Policy of Strategic Ambiguity: a Dilemma of Deterrence" Journal of Contemporary China 12:35

Pinsker, Roy, "Drawing a Line in the Taiwan Strait: 'Strategic Ambiguity and Its Discontents," Australian Journal of International Events 57:2 (July 2003)

Phillips, Steven, "Between Assimilation and Independence: Taiwanese Political Aspirations Under Nationalist Chinese Rule, 1945-1948," Taiwan: A New History, Murray A. Rubinstein, ed., (M.E. Sharpe, Armonk, NY) 1999

Quan Jing, "Militarization of the Taiwan Strait Issue," Reflections on the Triangular Relations of Beijing-Taipei, Washington since 1995, ed. Shiping Hua, (Palgrave MacMillan: New York, 2006)

Schelling, Thomas, The Strategy of Conflict (Oxford University Press: New York, 1977)

Shepherd, John R., "The Island Frontier of the Ch'ing," Taiwan: A New History, Murray $\quad$ A. Rubinstein, ed., (M.E. Sharpe, Armonk, NY) 1999

Will, John E., "The Seventeenth Century Transformation: Taiwan Under the Dutch and the Cheng Regime," Taiwan: A New History, Murray A. Rubinstein, ed., (M.E. Sharpe, Armonk, NY) 1999

$\mathrm{Wu}, \mathrm{Yu}$-Shan, "From Romantic Triangle to Marriage? Washington-Beijing-Taipei Relations in Historical Comparisons" Issues \& Studies 41:1 (March 2005)

Zagare, Frank C. and Kilgour, D. Marc, "Alignment Patterns, Crisis Bargaining, and Extended Deterrence: A Game-Theoretic Analysis," International Studies Quarterly 2003 No. 47

Zagoria, Donald S., Breaking the China-Taiwan Impasse, (Praeger: Westport, 2003) 


\section{CURRICULUM VITAE}

NAME: William David Frost

ADDRESS: Political Science Department

Ford Hall

University of Louisville

Louisville, KY 40292

DOB: $\quad$ Louisville, KY - June 24, 1982

\section{EDUCATION}

\& TRAINING: B.A., East Asian Studies

Oberlin College

2000-04

M.A., Political Science

University of Louisville

2005-07 